\title{
22. RED SEA EVAPORITES: A PETROGRAPHIC AND GEOCHEMICAL STUDY
}

\author{
Peter Stoffers, Laboratorium für Sedimentforschung, Universität Heidelberg, Germany \\ and \\ Robert Kühn, Kali-Forschungs-Institut der Kali u. Salz A.G., Hannover, Germany
}

\section{INTRODUCTION}

One of the major shipboard findings during Leg 23 drilling in the Red Sea was the presence of late Miocene evaporites at Sites 225, 227, and 228 (Figure 1).

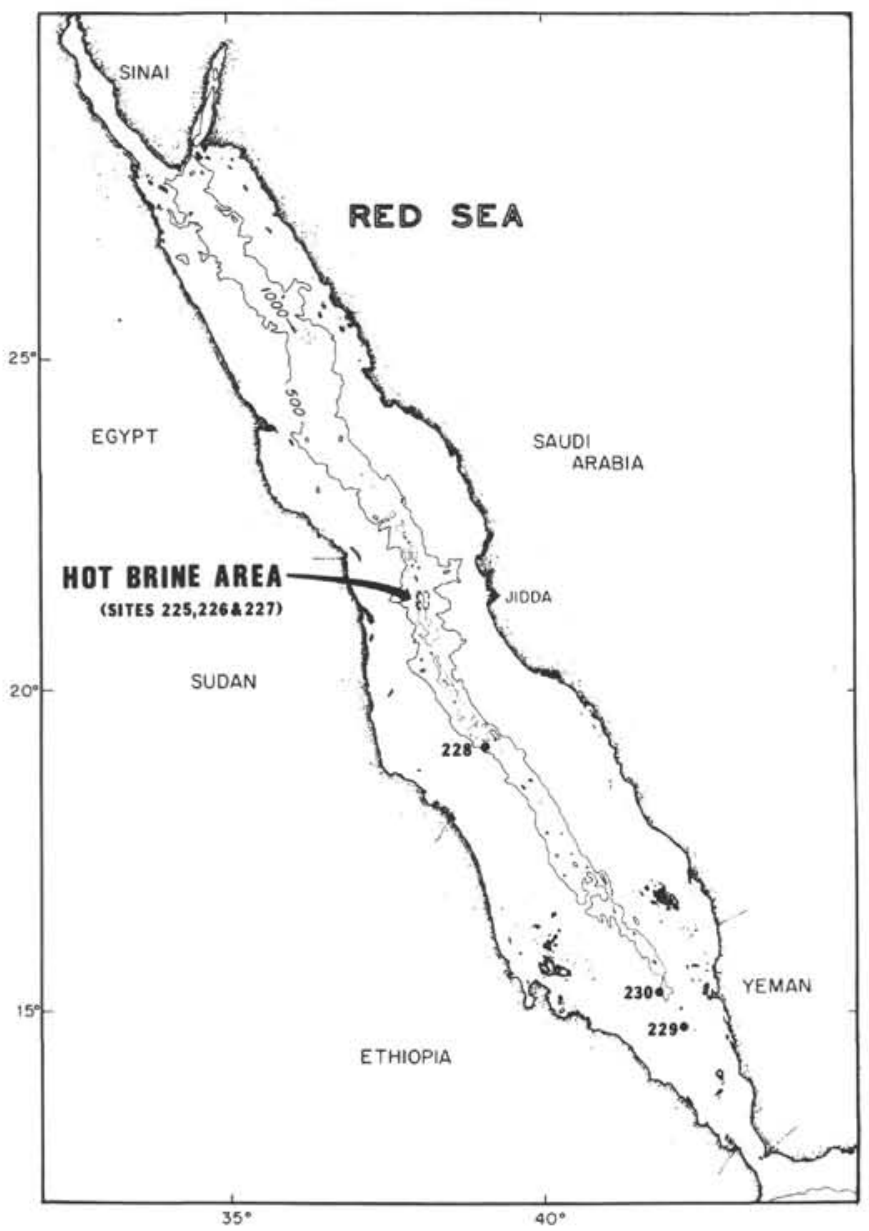

Figure 1. Leg 23 drill sites in the Red Sea.

The top of the evaporite sequence correlates with a strong reflector (Reflector S) which has been mapped over much of the Red Sea (Ross et al., 1969, Phillips and Ross, 1970). This indicates that the Red Sea appears to be underlain by late Miocene evaporites throughout most of its extent.

Miocene sediments, including evaporites, are known from a few outcrops along the coastal plains of the Gulf of Suez to lat $14^{\circ} \mathrm{N}$ (Sadek, 1959, cited in Friedman, 1972; Heybroek, 1965; Friedman, 1972). Along the length of the Red Sea, the presence of Miocene salt is indicated by seismic reflection studies (Lowell and Genik, 1972) and confirmed by drilling. The recently published data from deep exploratory wells (Ahmed, 1972) demonstrate the great thickness of clastics and evaporites which were deposited in the Red Sea depression during Miocene time.

The Red Sea evaporites are of the same age as the evaporites found by deep sea drilling (DSDP Leg 13) in the Mediterranean Sea. Therefore, Reflector S in the Red Sea is comparable to Reflector $\mathrm{M}$ in the Mediterranean. It is assumed that during Miocene time a connection between these two basins was established (Coleman, this volume) resulting in a similar origin for the evaporites deposited in the Red Sea and in the Mediterranean Sea. The origin of the Mediterranean evaporites has been discussed in great detail (Hsü et al., 1973; Nesteroff, 1973; Friedman, 1973).

The formation of evaporites may be interpreted by three different hypotheses.

1) Evaporation of a shallow restricted shelf sea or lagoon which receives inflows from the open ocean.

2) Evaporation of a deep-water basin which is separated from the open ocean by a shallow sill (Schmalz, 1969).

3) Evaporation of playas or salt lakes which are situated in desiccated deep basins isolated from the open ocean (Hsü et al., 1973).

The purpose of this study is to show whether one of these models might apply to the formation and deposition of the Red Sea evaporites. Therefore, a detailed petrographic and geochemical investigation was carried out.

\section{PETROGRAPHIC DESCRIPTION}

The stratigraphy of the evaporite sequence encountered at Sites 225, 227, and 228 is shown in Figure 2, which also indicates the mineralogy of the interbedded black shales. The photographed evaporite cores can be seen in the site report chapters for Sites 225, 227, and 228. Forty selected samples of the evaporite rocks from the Red Sea boreholes were studied in thin section under the petrographic microscope. All anhydrite samples were X-rayed in order to clarify the presence of gypsum, dolomite, calcite, and magnesite. The structure and texture of the rocks were described according to Maiklem et al. (1969). 


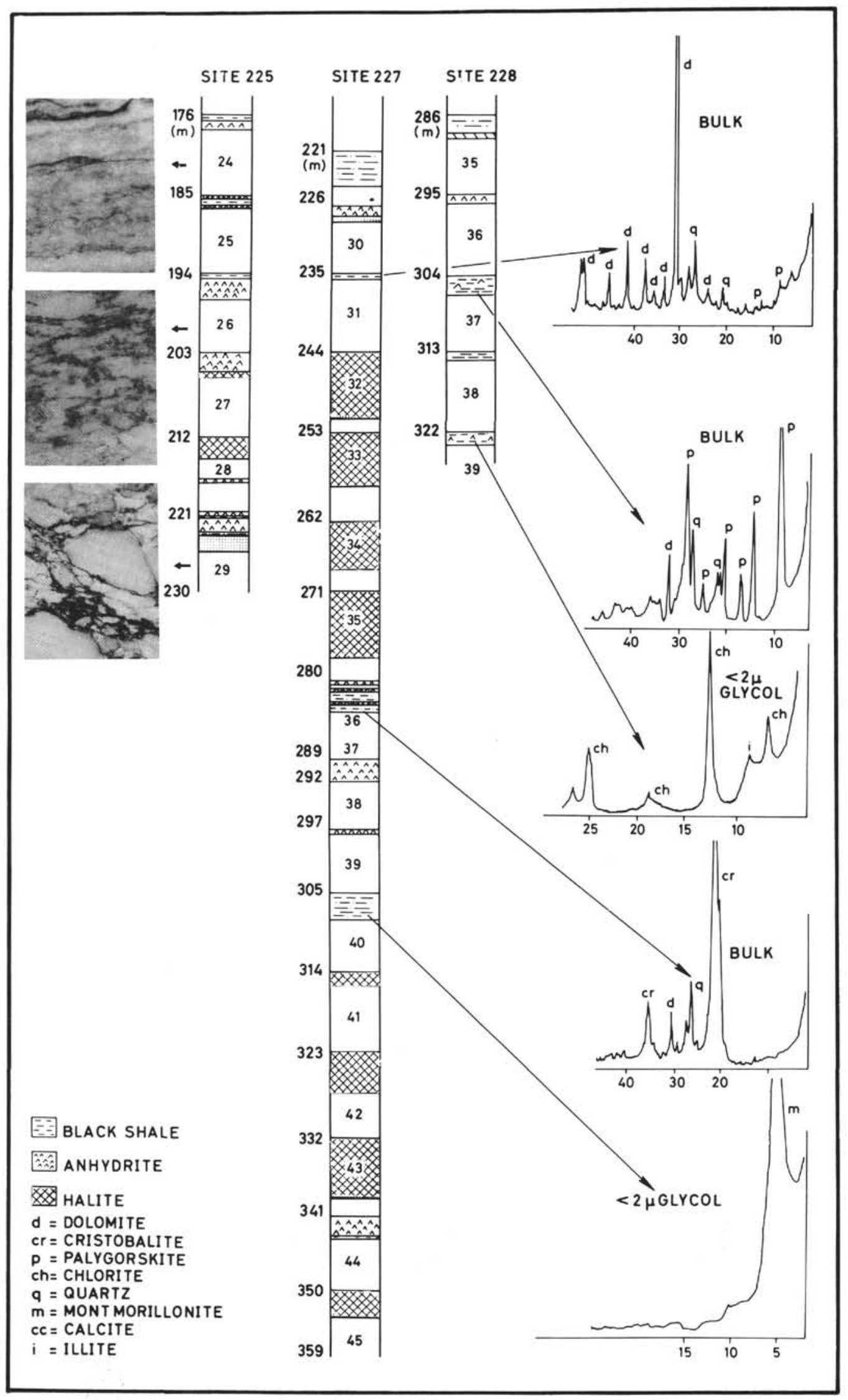

Figure 2. Stratigraphy of the evaporites encountered at Sites 225, 227, 228 and the mineralogy of the interbedded black shales. 


\section{Site 225}

Site 225 is situated 10 miles east of the Atlantic II Deep in a water depth of 1228 meters. Two hundred and thirty meters of sediment was continuously cored, including 53 meters of evaporites.

At the base of this hole (Samples 29-3, 0-150 cm;29-2, $90-150 \mathrm{~cm}$ ) white to gray rock salt was recovered. Bedding (3-7 $\mathrm{cm}$ apart) of cloudy and clear white halite occurred. Thin anhydrite layers $(0.2$ to $1 \mathrm{~cm})$ are intercalated within these beds. The dip of the anhydrite layers ranges up to $15^{\circ}$. Thin section examination $(29-3,100-103 \mathrm{~cm}$; Figure 3) reveals medium to coarse crystalline halite $(2-3 \mathrm{~mm}$ in diameter). Fine polyhalite needles $\left(2 \mathrm{CaSO}_{4} \cdot \mathrm{MgSO}_{4}\right.$. $\left.\mathrm{K}_{2} \mathrm{SO}_{4} \cdot 2 \mathrm{H}_{2} \mathrm{O}\right)(0.75 \mathrm{~mm}$ in length, $0.05 \mathrm{~mm}$ in width) are stringlike interspersed in the pore spaces of halite crystals. Twinning of the polyhalite crystals is found quite frequently. In larger pore spaces the polyhalite occurs as densely felted needles $(29-3,100-103 \mathrm{~cm}$; Figure 4$)$. The cloudy appearance of the gray halite is due to scattered brine inclusions. The linear orientation of the inclusions often produced crystal structures known as "hopper" and "chevron" which indicate a primary origin (Dellwig, 1953; Wardlaw and Schwerdtner, 1966). These structures disappear on recrystallization resulting in more transparent larger crystals clear of opaque inclusions.

The layering of clear and cloudy salt with intercalated thin anhydrite bands is typical of the halite recovered on Leg 23 drilling in the Red Sea. No obvious cyclic relationship is observed between these features. The absence of a statistical correlation between clear salt, cloudy salt, and anhydrite layers is reported by Fuller and Porter (1969) from the Devonian and Mississippian salt deposits of Alberta and North Dakota and by Dellwig (1968) from the Hutchinson salt deposit in Kansas. These authors explain the alteration of clear and cloudy salt by changes in the rate of evaporation which reflect changes in climatic conditions. The thickness of the halite laminae is determined by seasonal dilution (removal and recrystallization), whereas the thickness of the anhydrite laminae is determined by seasonal reconcentration.

The halite sequence is topped by a small interval of slightly layered anhydrite $(29-2,87-90 \mathrm{~cm})$ followed by typically nodular anhydrite $(29-2,6-81 \mathrm{~cm})$. Black shales are intercalated within the anhydrite $(29-2,81-87 \mathrm{~cm} ; 29-1$, $60-67 \mathrm{~cm})$. They are predominantly composed of montmorillonite and smaller amounts of cristobalite. These shales are thought to have originated from interbedded volcanic material. The anhydrite structure is described best as distorted nodular mosaic $(29-2,10-20 \mathrm{~cm}$; Figure 5). The white nodules (up to $3 \mathrm{~cm}$ in diameter) are separated by thin greenish seams. Under the petrographic microscope the nodules appear to be a randomly arranged combination of microcrystalline and small lath-shaped crystals (0.05-0.1 $\mathrm{mm}$; Figure 6). The nodules are bound by dark brownish streaks of opaque, probably organic-rich, material and very fine grained dolomite $(\sim 0.003 \mathrm{~mm})$ which were separated from the matrix during growth or deformation of the anhydrite nodules.

Core 28 and the lower part of Core 27, Section 2 consist of bedded clear white and dusty gray halite (about 2 to 4 $\mathrm{cm}$ apart) which is intercalated by thin anhydrite layers
$(0.5-1 \mathrm{~cm})$. The anhydrite layers show dips between $10-25^{\circ}$. The thin sections $(28-3,95-105 \mathrm{~cm} ; 27-2,110-112 \mathrm{~cm})$ show medium to coarsely crystalline halite ( 2 to $4 \mathrm{~mm}$ ) with partly mosaic structure (Figures 7,8 ). Within the halite there are thin layers of needle-like anhydrite which locally forms rounded aggregates. In the dusty gray halite-oriented liquid, inclusions are very abundant.

The halite is topped by a small interval of light gray, slightly laminated anhydrite $(27-2,69-87 \mathrm{~cm})$ followed by distorted nodular to bedded nodular mosaic anhydrite (27-2, 0-60 cm; 27-1, 90-150 cm; Figure 9). Petrographic microscope examination $(27-1,119-122 \mathrm{~cm})$ shows that the matrix is a fine crystalline anhydrite. Besides fine-grained dolomite and streaks of opaque, probably organic-rich, material, clusters of coarse crystalline anhydrite occur which sometimes display sheath-like to stellate patterns (Figure 10). The top of Core 27, Section 1 consists of a more laminated anhydrite. A thin layer of greenish gray fine-grained dolomite $(27-2,60-69 \mathrm{~cm})$ is intercalated in the anhydrite, indicating a regressive stage of evaporation.

Core 26 is mainly composed of white anhydrite with bedded nodular mosaic structure $(26-2,133-136 \mathrm{~cm}$; Figure $11)$. The nodules are separated by black opaque, probably organic-rich, matter and small amounts of carbonate material. The matrix again is a very fine crystalline anhydrite of aligned felted texture $(\sim 0.005 \mathrm{~mm})$. Within this ground mass there are porphyrotopes of coarse crystalline anhydrite (26-1, 140-144 cm; Figure 12). These aggregates are thought to have formed by diagenetic metablastese.

The anhydrite is topped by a black shale sequence (26-1, $1-34 \mathrm{~cm})$. The thin section $(26-1,13-16 \mathrm{~cm})$ reveals the presence of slightly laminated algal oncolites (Figure 13 a, $\mathrm{b}, \mathrm{c})$. The oncolites consist of very fine-grained dolomite (0.005-0.01 $\mathrm{mm})$ impregnated with opaque material, probably rich in organic matter, and some pyrite. The cavities within the oncolites are often filled with secondary anhydrite, sometimes with chalcedony.

A finely laminated massive anhydrite of alternating medium gray and white layers is found in the lower section of Core $25(137-150 \mathrm{~cm})$. The thickness of the individual layers is about 1-1.5 mm. The upper part of the core consists of dark shales. X-ray analyses show that the shales are mainly composed of dolomite (up to 60\%), layer silicates, palygorskite, analcite, quartz, feldspar, and some pyrite. The dominant clay mineral is an illitemontmorillonite mixed layer. The formation of the black dolomite shales is related to regressive evaporation caused by a strong dilution of the brine.

The top $10 \mathrm{~cm}$ of Core 25 and the major part of Core 24 $(67-150 \mathrm{~cm})$ consist of wavy laminated massive anhydrite (Figure 14). The laminations are described best as stromatolites. They are composed of alternating white $2-4 \mathrm{~mm}$ and medium gray 0.5-1 mm thick layers. The thin section (24-1, $70-74 \mathrm{~cm}$; Figure 15) shows very uniform fine crystalline lath-shaped anhydrite $(\sim 0.015 \mathrm{~mm})$ in subparallel orientation. The darker layers consist of scattered micron sized opaque, probably organic, material and very fine grained dolomite.

A dark gray to black semilithified to lithified dolomitic silty claystone (Core $24-1,0-70 \mathrm{~cm}$; Cores $23,22,21$ ) tops 


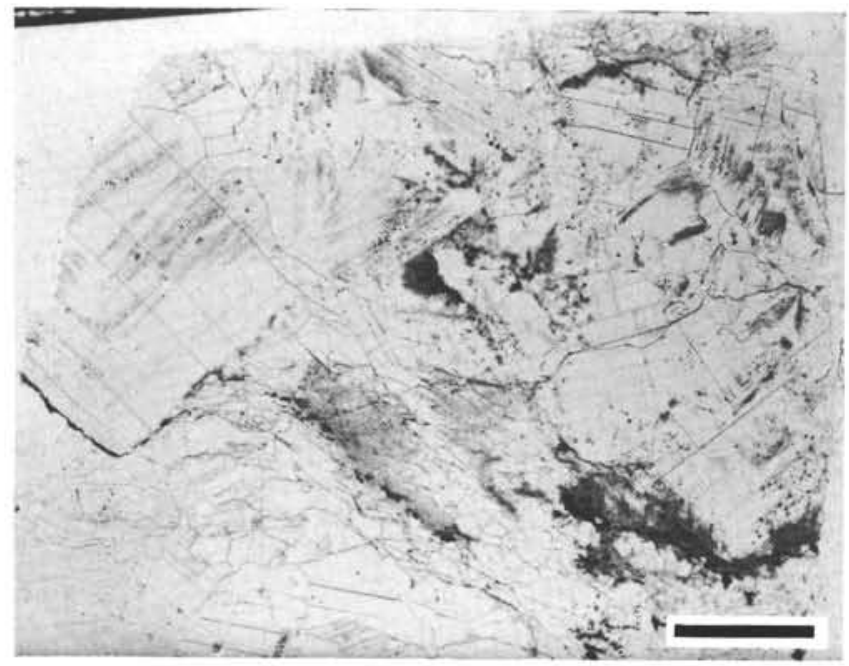

Figure 3. Cloudy halite with oriented liquid inclusions and interspersed polyhalite $(225-29-3,100-103 \mathrm{~cm})$. Scale bar represents $4 \mathrm{~mm}$.

the evaporite section of Site 225. The increasing marine fauna found in the upper cores of this sequence indicates the change to open marine conditions.

\section{Site 227}

Site 227 is situated about two miles east of the edge of the Atlantis II Deep in a water depth of 1795 meters and 359 meters of Quaternary to late Miocene sediments were cored, including 133 meters of late Miocene and probably older anhydrite and halite.

The lowermost core $(45-1,-2)$ consists of bedded alternating white and light gray rock salt. In general, the individual layers vary between 2 and $5 \mathrm{~cm}$. Anhydrite layers 0.2 to $10 \mathrm{~mm}$ thick ( 2 to $6 \mathrm{~cm}$ apart) are intercalated within this halite sequence. The thin section (45-1, 112-117 $\mathrm{cm}$; Figure 16) shows coarse crystalline halite $(5-8 \mathrm{~mm})$ interspersed with polyhalite needles $(0.05-0.08 \mathrm{~mm})$. Liquid inclusions are abundant within the gray halite forming typical chevron and hopper structure.

Anhydrite is found in Core 44, Sections 1 and 2. In the lower part of Section $2(70-150 \mathrm{~cm})$, the anhydrite is of distorted bedded nodular structure. The white nodules are surrounded by greenish gray dolomite seams. The top of Section 2 and the entire Section 1 consist of thin layers (1-2 $\mathrm{mm})$ of massive whitish gray anhydrite interbedded with layers of medium gray material $(\sim 0.03 \mathrm{~mm}$; Figure 17). Petrographic microscope examination $(44-2,65-70 \mathrm{~cm}$; Figure 18) reveals very fine laminated anhydrite of aligned felted texture $(0.03-0.06 \mathrm{~mm})$. The lath-shaped crystals are oriented parallel to the bedding planes. The darker layers are composed of dolomite impregnated with organic matter and very fine grained pyrite.

The entire Core 43 (Sections 1 to 5) and Core 42 (Sections 1 to 3 ) are represented by irregularly bedded clear white and gray halite. Very distinct layers of anhydrite $(\sim 1.5 \mathrm{~cm})$ interbedded within the halite occur in Sections 3,4 , and 5 , whereas the anhydrite layers in the upper section of Core 43 and in Core 42 are only slightly

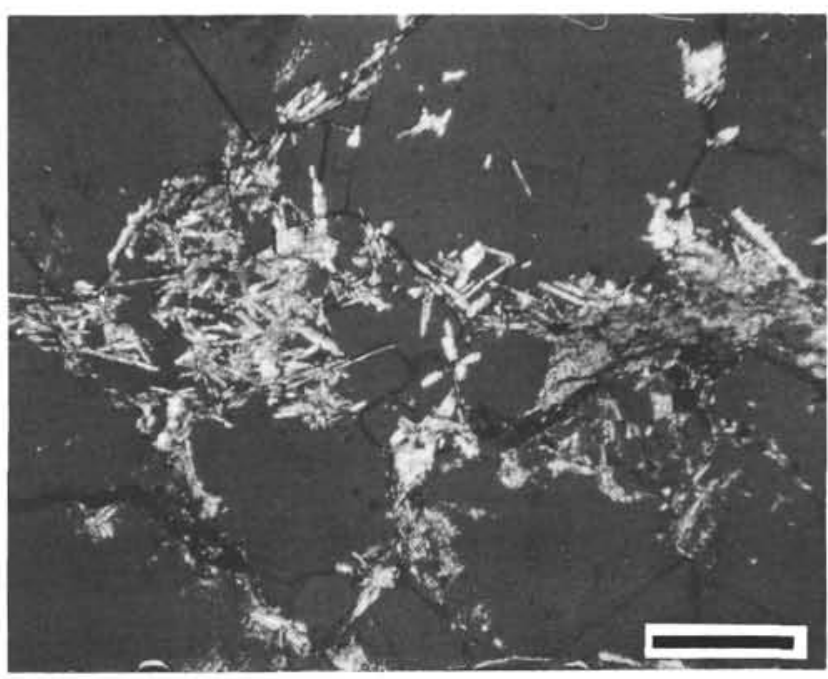

Figure 4. Clusters and fine needles of polyhalite in halite (225-29-3, 100-103 cm). Partially crossed nicols. Scale bar represents $1 \mathrm{~mm}$.

indicated. Clear white halite dominates this upper sequence. The thin section (43-2, 20-25 cm; Figure 19) shows medium coarse crystallized halite $(1-2 \mathrm{~mm})$ of generally mosaic structure. The halite is interbedded by a $1.5 \mathrm{~cm}$ thick anhydrite layer. The subfelted anhydrite crystals $(\sim 0.07 \mathrm{~mm})$ are in random orientation. Within the anhydrite there are dark stringers of opaque, probably organic-rich, material.

The lowermost $4 \mathrm{~cm}$ of Core 41 , Section 1 is composed of bedded massive anhydrite topped by alternating white and gray halite $(4-8 \mathrm{~cm}$ apart) with intercalated $2-10 \mathrm{~mm}$ thick anhydrite layers. Under the microscope (41-1, $105-110 \mathrm{~cm}$; Figure 20), the halite is coarse crystalline and shows a mosaic structure. The microcrystalline anhydrite $(0.02-0.05 \mathrm{~mm})$ is often aligned with the halite particles. This concentration of anhydrite along the halite rims is caused by anhedral halite growth which seems to replace euhedral halite crystals.

Core 40 , Sections 1 and 2 consist of black shales which were completely fractured by drilling. X-ray diffraction shows that the shales are composed, in general, of montmorillonite and smaller amounts of calcite, feldspar, quartz, clinoptilolite, analcite, pyrite, dolomite, gypsum, and anhydrite. The abundant montmorillonite and the presence of zeolites suggest a strong volcanic influence.

Core 39, Section 1 and Core 38, Section 1 are represented by massive anhydrite with a slight indication of bedding. The thin section (38-1; Figure 21) shows a lath-shaped anhydrite matrix interspersed with large fibrous or sheath-like anhydrite aggregates. The recrystallization of the anhydrite has caused the scattered dolomite and opaque material to migrate to the boundaries of the aggregates.

Anhydrite of bedded mosaic structure is found in Core 37, Sections 1 and 2. The thin section (37, CC; Figure 22) shows fine crystalline dolomite layers $(0.005-0.02 \mathrm{~mm})$ impregnated with opaque material. The dolomite layers $(0.05-0.1 \mathrm{~mm}$ thick) are intercalated within the lath-shaped anhydrite matrix. 


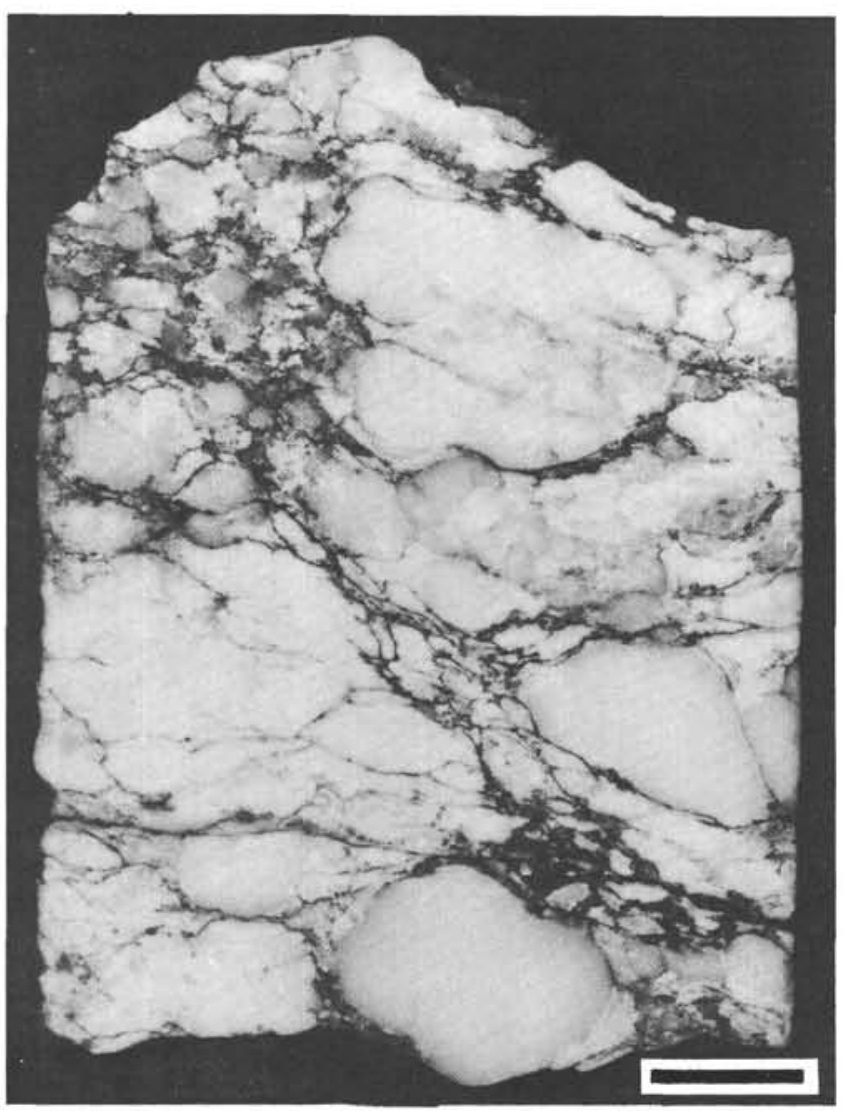

Figure 5. Nodular anhydrite $(225-29-2,10-20 \mathrm{~cm})$. Scale bar represents $1 \mathrm{~cm}$.

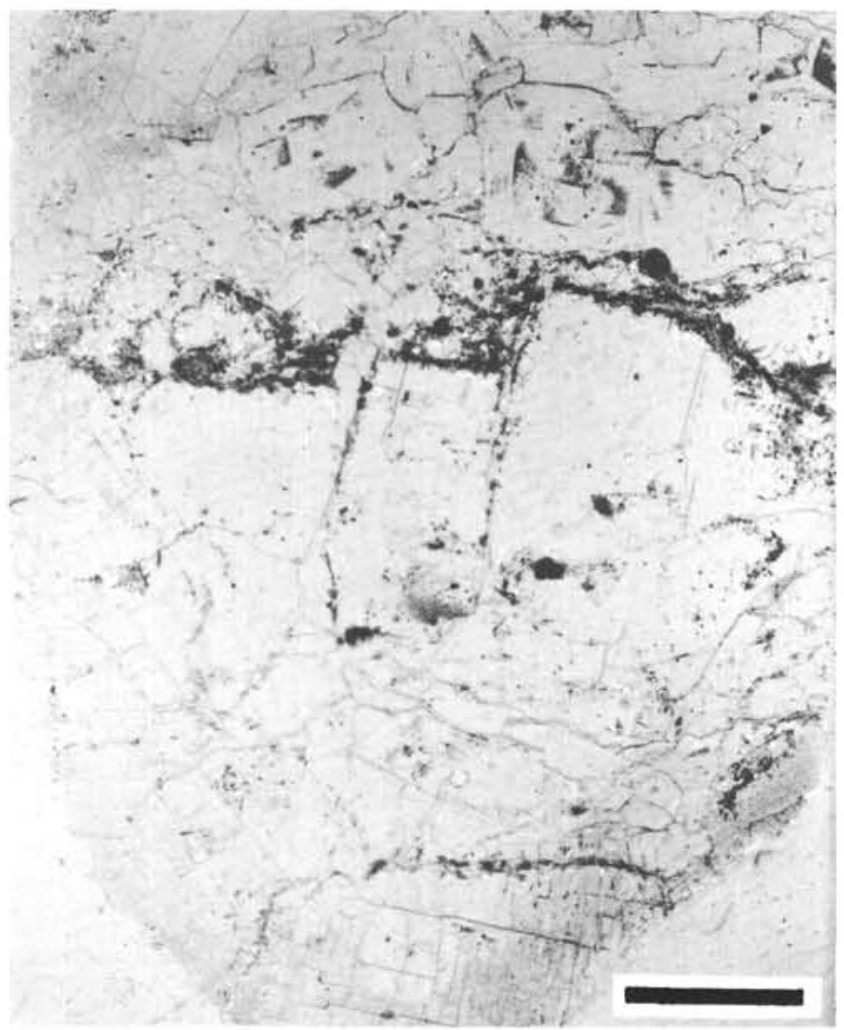

Figure 7. Medium to coarsely crystalline halite intercalated with thin anhydrite layers $(225-28-3,95-105 \mathrm{~cm})$. Scale bar represents $4 \mathrm{~mm}$.

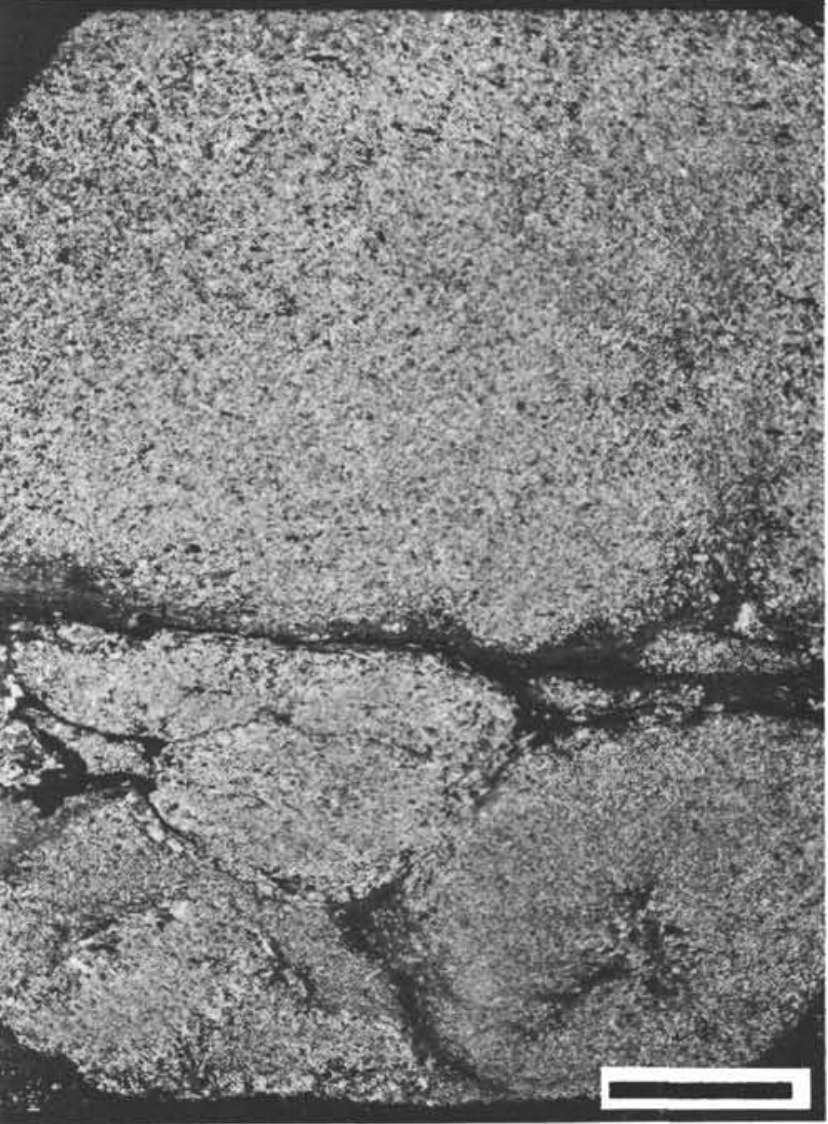

Figure 6. Nodules consisting of microcrystalline and small lath-shaped anhydrite (225-29-2, 10-20 cm). Scale bar represents $4 \mathrm{~mm}$. Oriented thin section. Crossed nicols.

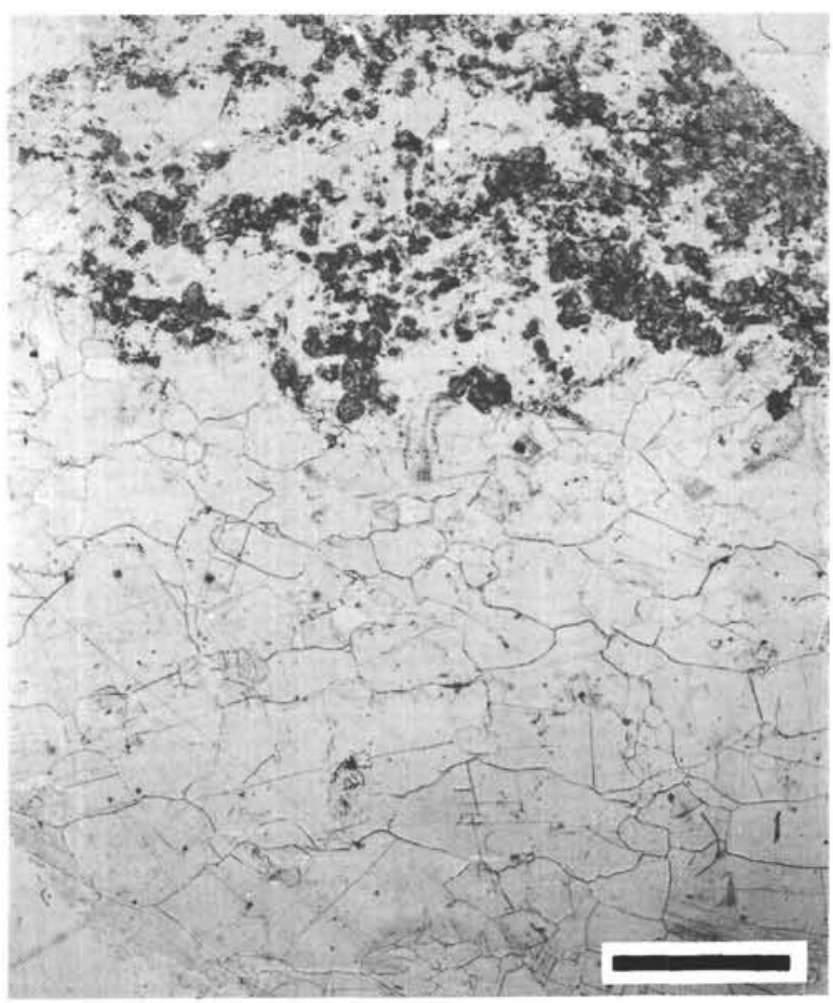

Figure 8. Medium to coarsely crystalline halite with rounded anhydrite aggregates $(225-27-2,110-112 \mathrm{~cm})$. Scale bar represents $4 \mathrm{~mm}$. 


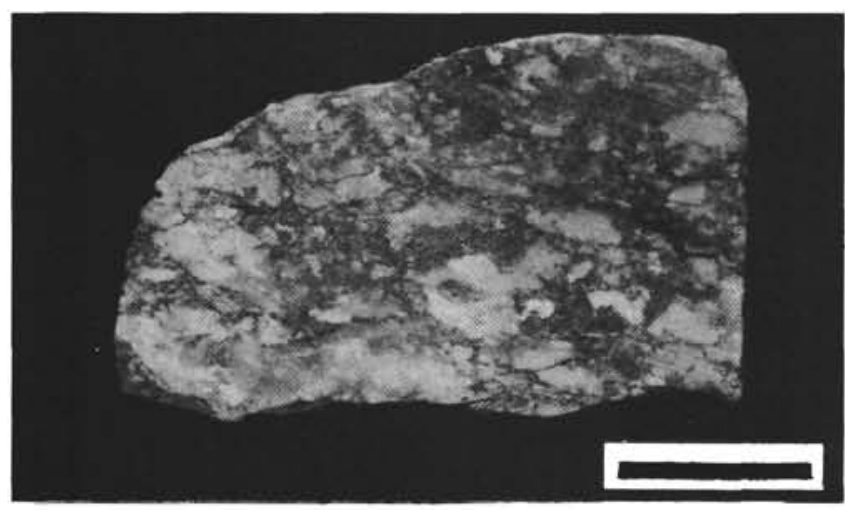

Figure 9. Anhydrite of distorted nodular mosaic structure (225-27-1, 119-122 cm). Scale bar represents $2 \mathrm{~cm}$.

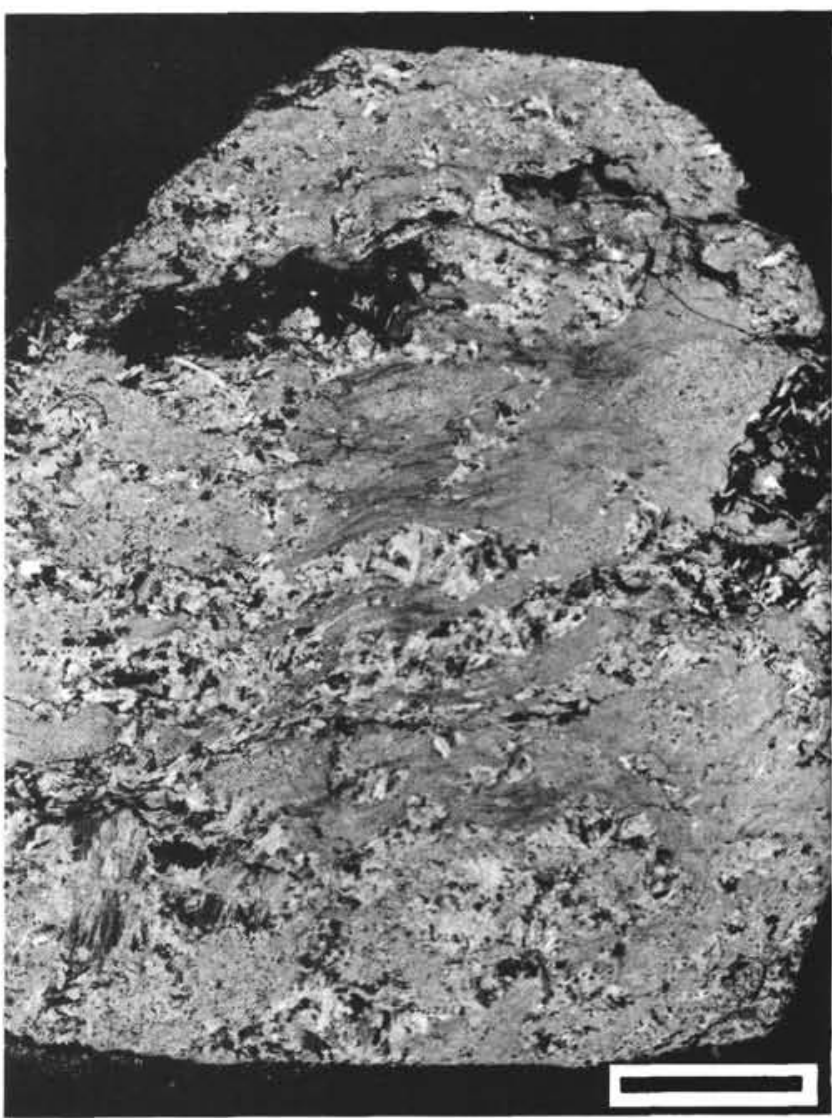

Figure 10. Fine crystalline anhydrite matrix, dark gray semi-opaque, probably organic-rich, streaks, fine-grained dolomite, clusters of coarse crystalline anhydrite (22527-1, 119-122 cm). Scale bar represents $4 \mathrm{~mm}$. Crossed nicols.

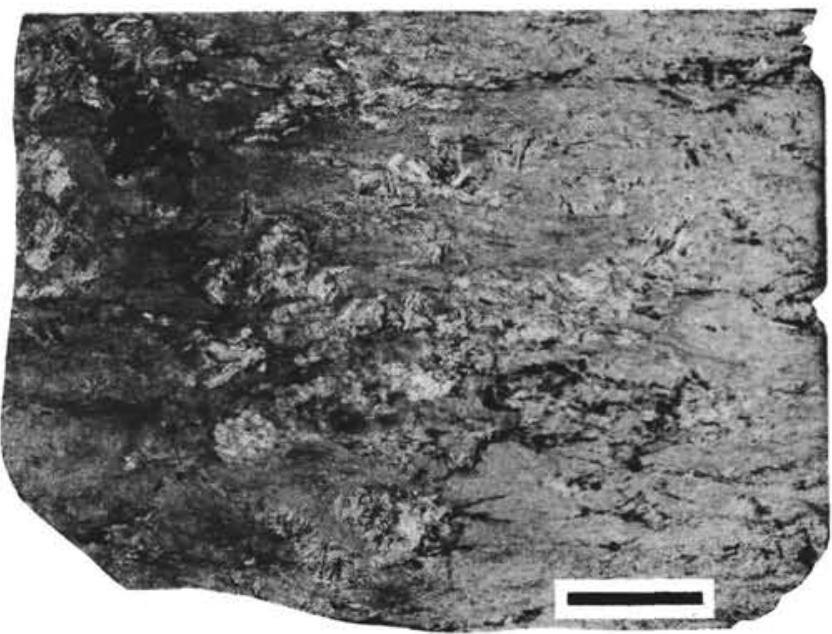

Figure 12. Fine crystalline anhydrite of aligned felted texture, streaks of opaque material, aggregates of coarse crystalline anhydrite $(225-26-1,140-144 \mathrm{~cm})$. Scale bar represents $4 \mathrm{~mm}$. Thin section is oriented. Crossed nicols. 


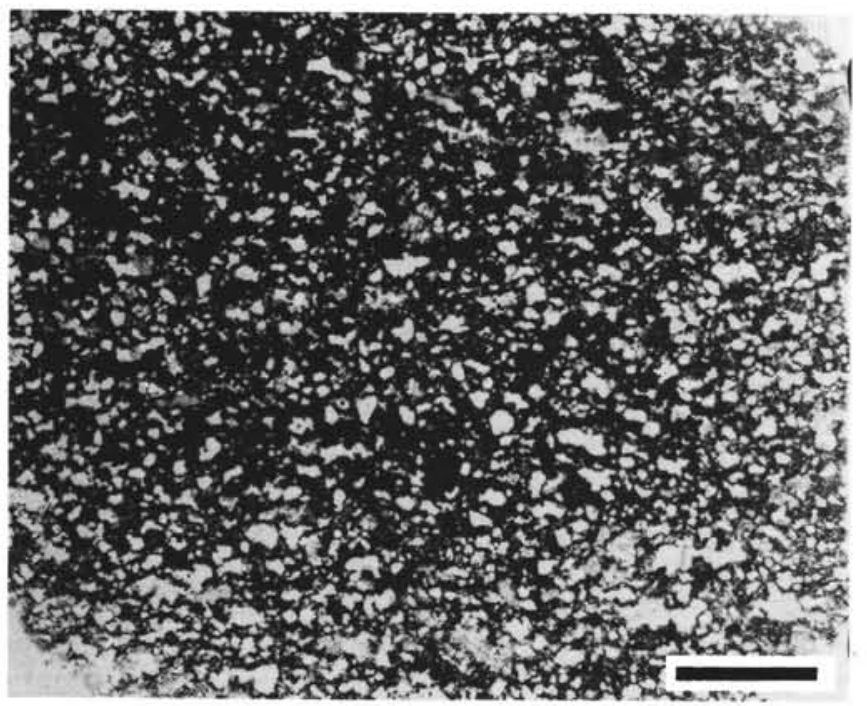

a

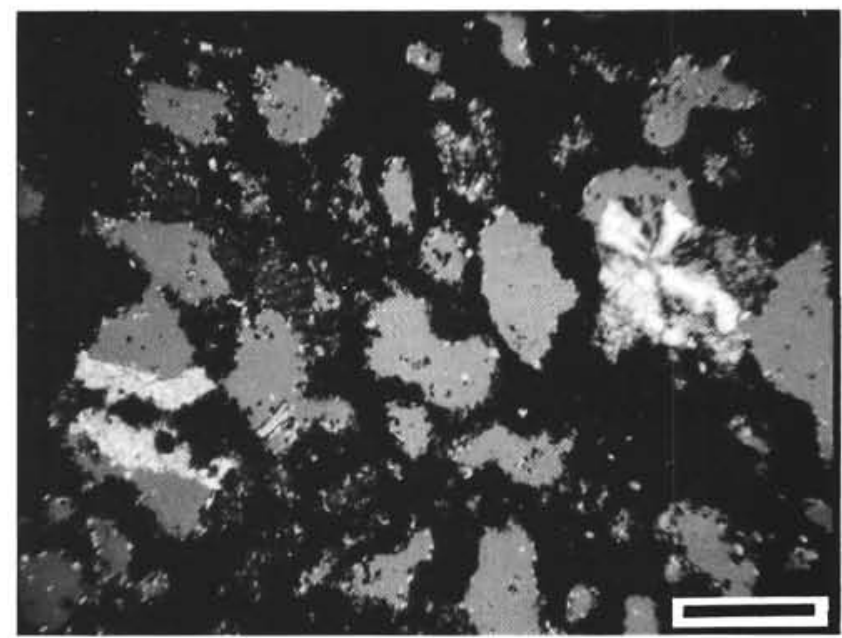

b

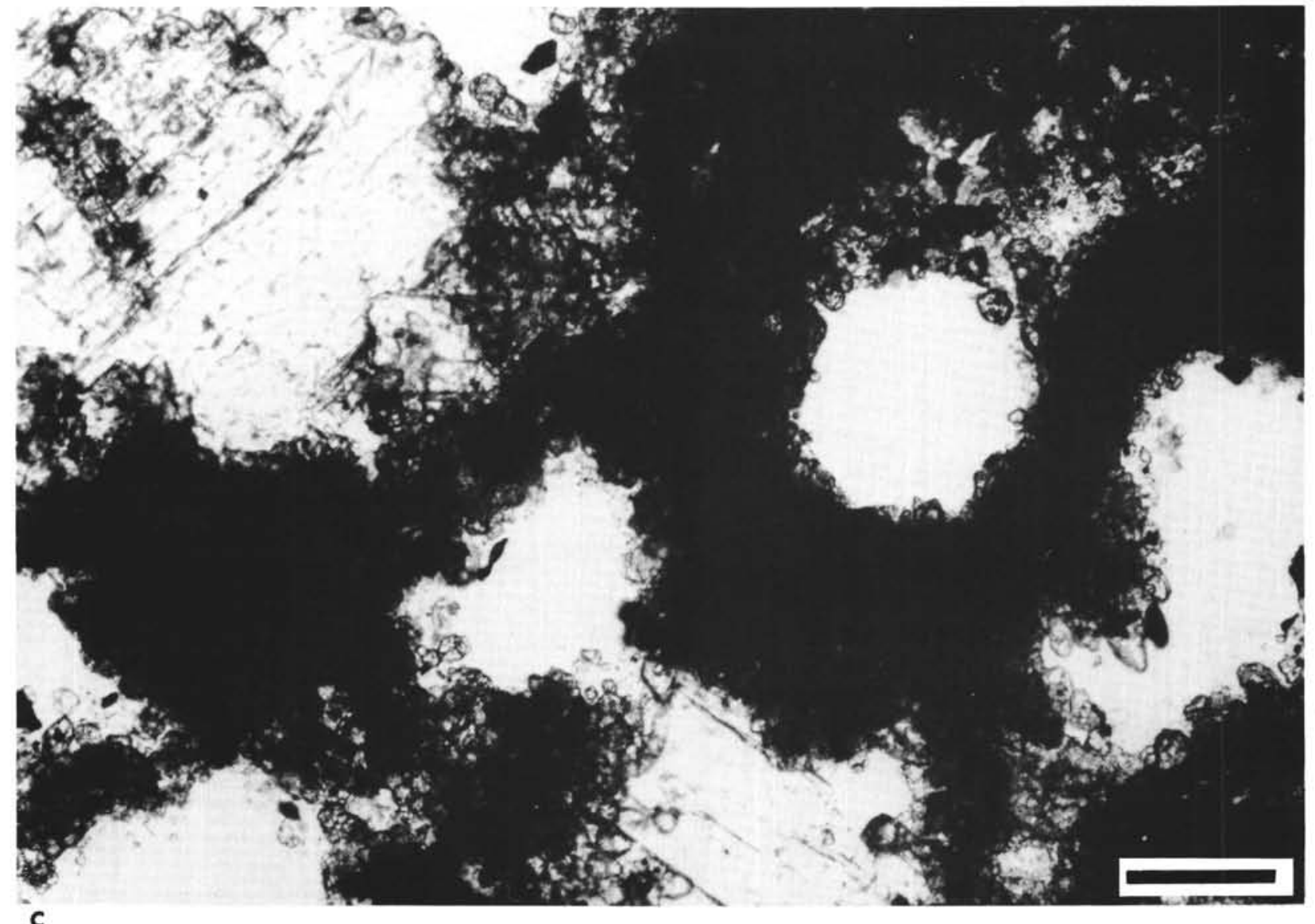

Figure 13. Oncolite structure (225-26-1): (a) scale bar represents $4 \mathrm{~mm}$; partially crossed nicols; (b) partially crossed nicols; some cavities filled with anhydrite and chalcedony; scale bar represent $0.5 \mathrm{~mm}$; and (c) fine grained dolomite impregnated with opaque, probably organicrich material; some anhydrite in the cavities; scale bar represents $0.1 \mathrm{~mm}$. 


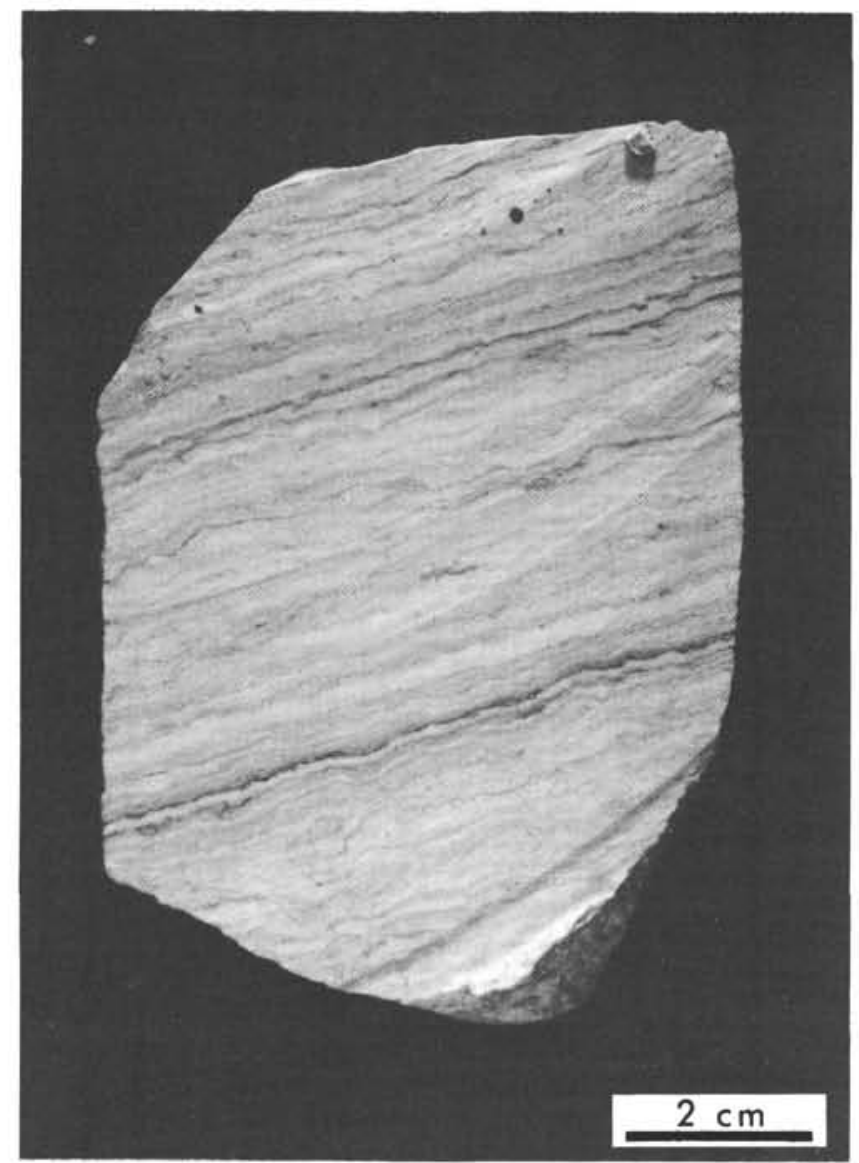

Figure 14. Wavy laminated anhydrite (stromatolites) of alternating white anhydrite and dark layers composed of dolomite and opaque material (225-24-1, 80-85 cm). Scale bar represents $2 \mathrm{~cm}$.

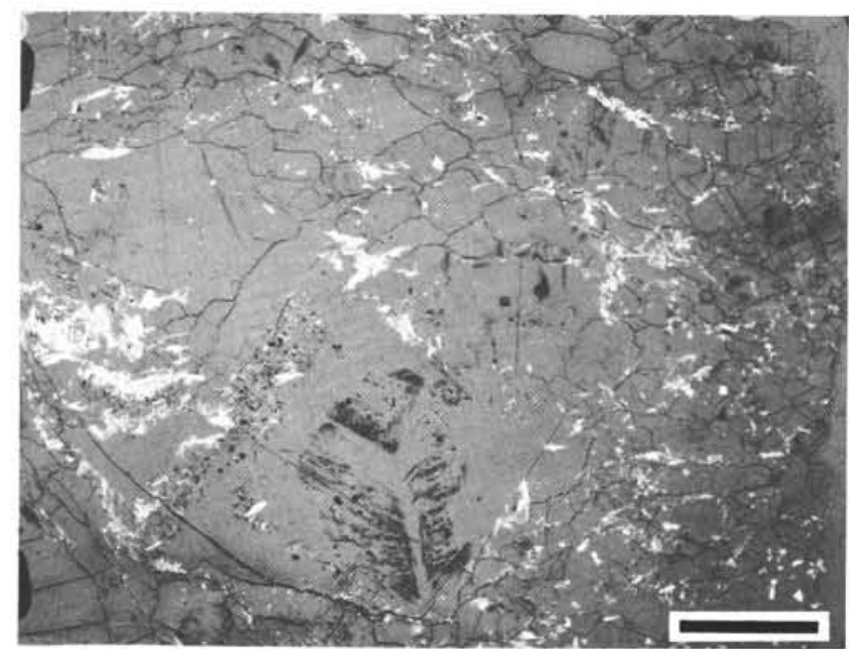

Figure 16. Coarse crystalline halite interspersed with polyhalite needles, oriented liquid inclusions (227-45-1, $112-117 \mathrm{~cm})$. Partially crossed nicols. Thin section is oriented. Scale bar represents $4 \mathrm{~mm}$.

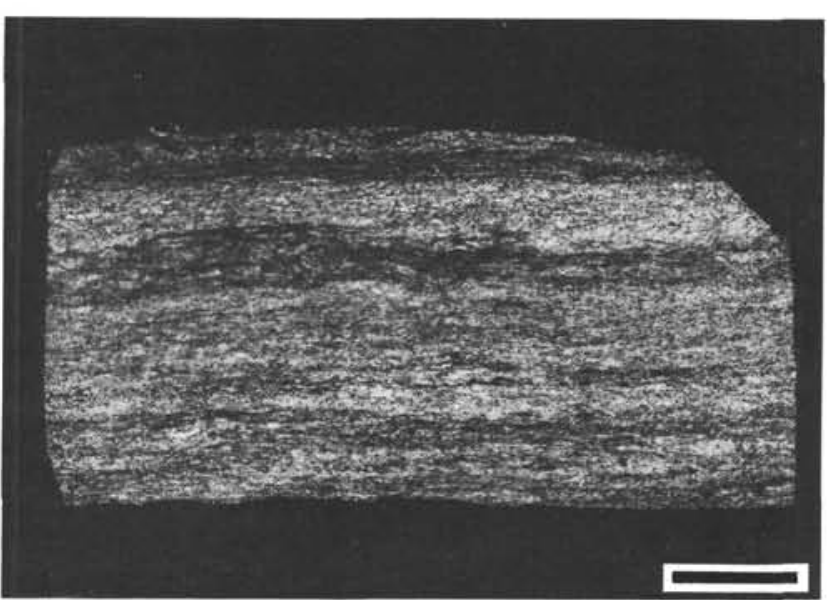

Figure 15. Fine crystalline anhydrite of aligned felted texture with alternating layers of opaque material interspersed with dolomite (225-24-1, 70-74 cm). Crossed nicols. Scale bar represents $4 \mathrm{~mm}$.

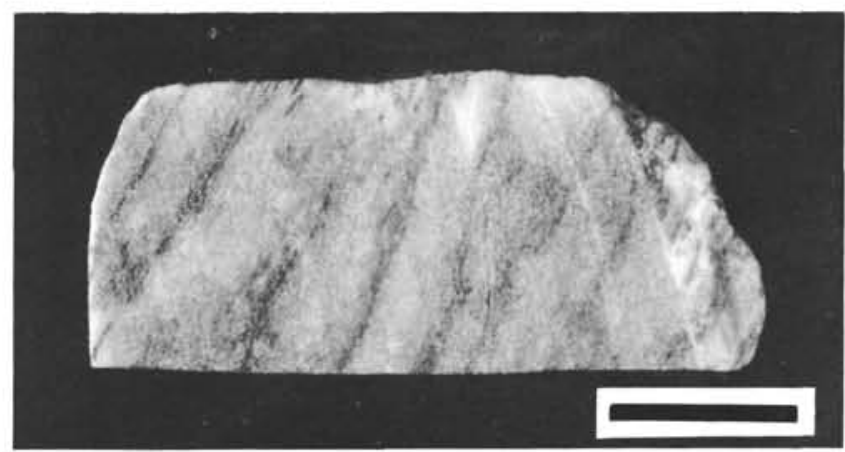

Figure 17. Bedded mosaic anhydrite with intercalated dark layers $(227-44-2,65-70 \mathrm{~cm})$. Scale bar represents $2 \mathrm{~cm}$. 


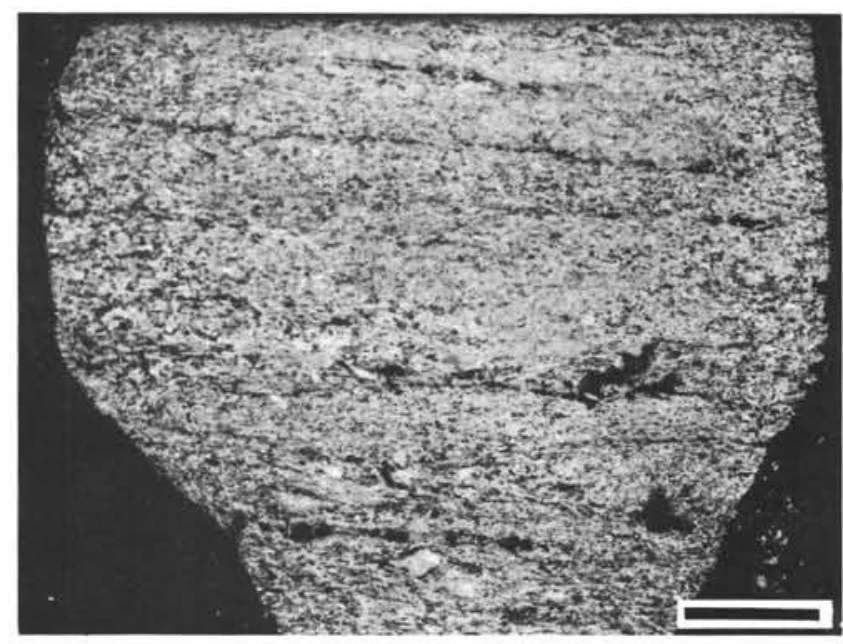

Figure 18. Fine laminated anhydrite of aligned felted texture. Dark layers consist of dolomite impregnated with opaque material (227-44-2, 65-70 cm). Crossed nicols. Thin section is oriented. Scale bar represents $4 \mathrm{~mm}$.

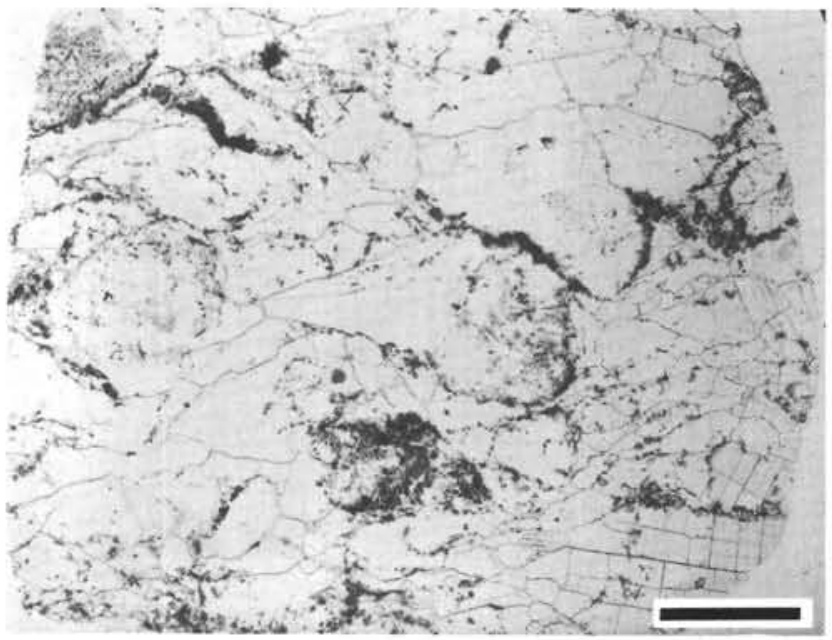

Figure 20. Coarse crystalline halite with microcrystalline anhydrite aligned with the halite particles (227-41-1, $105-110 \mathrm{~cm})$. Partially crossed nicols. Thin section is oriented. Scale bar represents $4 \mathrm{~mm}$.

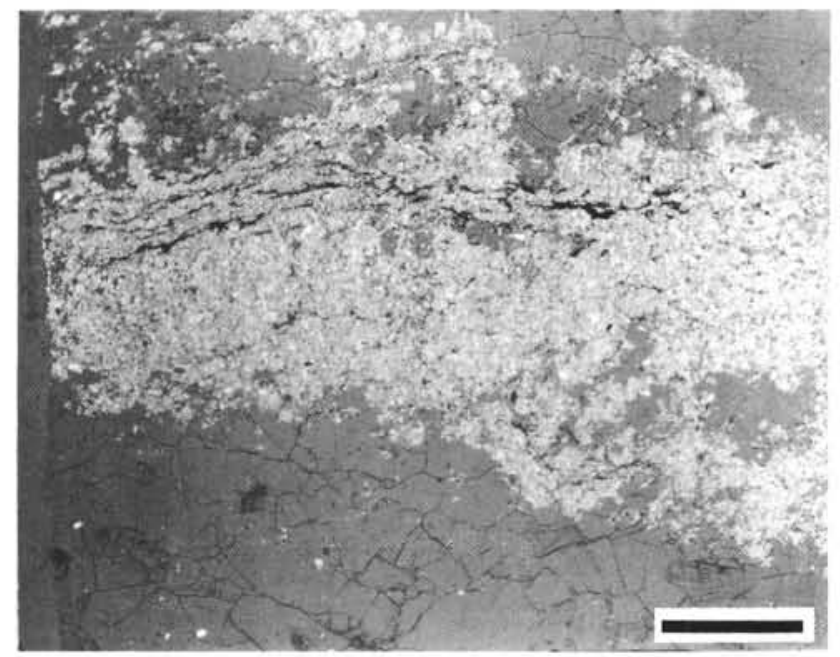

Figure 19. Coarse crystalline halite with interbedded anhydrite lcyer (227-43-2, 20-25 cm). Partially crossed nicols. Thin section is oriented. Scale bar represents $4 \mathrm{~mm}$.

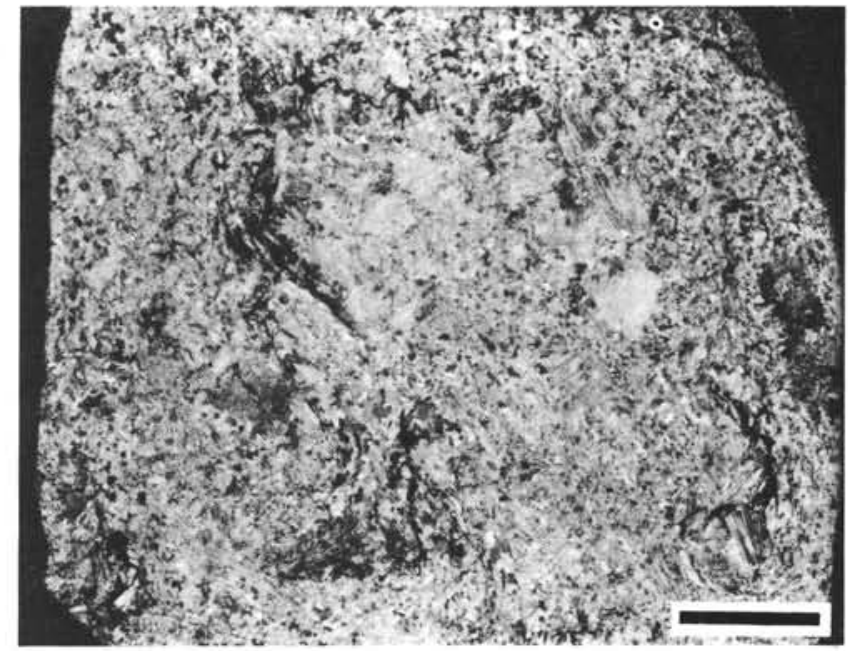

Figure 21. Lath-shaped anhydrite matrix interspersed with large fibrous or sheath-like anhydrite aggregates (227-38-1, 130-134 cm). Crossed nicols. Thin section is oriented. Scale bar represents $4 \mathrm{~mm}$. 
Interbedded black shales occur within the anhydrites of Core $36(36-3,70-150 \mathrm{~cm} ; 36-2,95-150 \mathrm{~cm})$. The shales were completely broken up by the drilling operation. X-ray examination reveals disordered cristobalite as the predominant constituent $(>80 \%)$ besides traces of palygorskite, zeolites, dolomite, quartz, feldspars, and pyrite. Nannofossils (Discoaster quinqueramus) and benthonic foraminifera are present in the core catcher of Core 36. Under the petrographic microscope, the microcrystalline cristobalite is finely laminated by opaque material probably rich in organic constituents (Figure 23). Scanning micrographs show typical silica spherules $(5-10 \mu)$ of disordered cristobalite. The spherules consist of irregularly oriented tubes and needles (Figures 24 a, b) described as lussatite (Berger and von Rad, 1972). The mineralogy of the black shales suggests volcanism as a source of the silica.

The anhydrite in Core 36, Section 3 has a massive structure with slight indications of bedding. Under the petrographic microscope (36-3; Figure 25), the anhydrite is of microcrystalline texture $(\sim 0.05 \mathrm{~mm})$. Intergrown clusters of coarse recrystallized anhydrite and authigenic quartz crystals (up to $3 \mathrm{~mm}$ ) are found within this fine-grained matrix. The quartz crystals often show twinning and frequently contain inclusions of anhydrite. These inclusions are oriented parallel to the crystal edges due to rhythmic growing of the quartz crystal (36-3; Figure 26). Quartz is generally common in saline deposits. It occurs partly as clastic grains and partly as an authigenic mineral with well developed idiomorphic forms. According to Grimm (1962), quartz frequently forms in saline sediments during an early stage of diagenesis. Idiomorphous quartz crystals with inclusions of anhydrite demonstrate that this anhydrite rock probably was of primary origin and not derived from gypsum by diagenesis. Due to the volume increase accompanying the transition to anhydrite, the inclusions of primary gypsum would have produced some fracturing. However, microscopic investigations show that the inclusions of anhydrite in the quartz completely fill the available space. No fractures could be observed.

Anhydrite of streaky structure is found in Core 36, Section 2 (Figure 27). Tails and pieces of greenish gray carbonate material are intercalated with dark gray anhydrite beds. The carbonate material was identified as magnesite by X-ray diffraction. Besides magnesite there are traces of pyrite. The thin section (36-2; Figure 28) shows microcrystalline anhydrite $(\sim 0.05 \mathrm{~mm})$ with slightly aligned orientation. The very fine crystalline magnesite (0.003-0.007 mm) occurs as clusters or streaks within the anhydrite. Core 36 , Section 1 is also composed of streaky anhydrite. Petrographic microscope examination (36-1; Figure 29) reveals anhydrite crystals of aligned felted texture. Lumps of anhydrite (up to $10 \mathrm{~mm}$ ) with sharp edges or straight sides are separated from one another by a magnesite matrix (0.007-0.02 mm). Some of these features might be deformed gypsum pseudomorphs (Borchert and Baier, 1953). The microcrystalline magnesite occurs as hypidiotopic to xenotopic grains. Frequently, magnesite forms ringlike aggregates which surround a single magnesite or pyrite grain. Ringlike magnesite aggregates within Zechstein anhydrites of Northern Germany have been described by Langbein (1961) and Kosmahl (1969). It is thought that these ringlike structures originated from recrystallization due to diagenesis.

A study of the available analyses of carbonate in salt rocks of Central Europe (Kühn, 1968) shows that along the margins of the basin, calcite, and more commonly, dolomite occurs, derived from relatively diluted brines; whereas, magnesite occurs exclusively in the sediments of the more highly concentrated brines of the interior of the basin. The distribution of carbonates is evidently related to the process of progressive concentration during which the heavier magnesium chloride solution accumulated in the deepest part of the basin. According to Link (1938, 1942), the dolomite and the magnesite have to be considered as early diagenetic.

The bottom of Core 35 consists of bedded massive light gray anhydrite interbedded with thin dark gray layers about $1 \mathrm{~mm}$ apart (Figure 30). Petrographic microscope examination (35-5, 115-123 cm; Figure 31) shows microcrystalline anhydrite $(\sim 0.05 \mathrm{~mm})$ interspersed with sheath-like anhydrite $(1-2 \mathrm{~mm})$. Dark layers $(0.02-0.1 \mathrm{~mm})$ are intercalated in the fine crystalline matrix and are composed of opaque, probably organic-rich, material and small dolomite grains $(\sim 0.004 \mathrm{~mm})$. The anhydrite is topped by bedded alternating clear white and medium gray halite (Sections 1-5). The thickness of the individual beds, generally, is about 3 to $7 \mathrm{~cm}$ with the exception of the lower part of Section $5(60-120 \mathrm{~cm})$, which is represented by a sequence of medium gray halite. Thin brownish green anhydrite layers $(0.5-1 \mathrm{~cm})$ are intercalated in the halite (Figure 32) at intervals of 1 to $7 \mathrm{~cm}$. In the medium gray halite of Section 5 , these laminations are only $0.5 \mathrm{~cm}$ apart. The thin anhydrite layers show dips up to $60^{\circ}$. The thin section $(35-3,53-60 \mathrm{~cm}$; Figure 33 ) reveals medium to coarse crystalline halite $(\sim 1 \mathrm{~mm})$ with clusters and streaks of lath-shaped anhydrite (0.1-0.2 mm). Recrystallization of the halite has caused the anhydrite to concentrate along the crystal boundaries of the halite.

Core 34 (Sections 1 to 4), Core 33 (Sections 1 to 4), and Core 32 (Sections 1 to 5) consist of alternating clear white and medium gray halite with interbedded thin anhydrite layers $(0.2 \mathrm{~mm})$. In Cores 32 and 33, the anhydrite layers are only slightly indicated. Clear white halite predominates this sequence. Under the petrographic microscope (33-1, $80-84 \mathrm{~cm}$; Figure 34 ), the medium to coarse crystalline halite $(>1 \mathrm{~mm})$ of mosaic structure is oriented parallel to the bedding plane. Polyhalite needles are found in clusters or stringers interspersed within the halite.

The halite sequence is topped by dark brown to black shales (Core 31, Section 1, 0-70 cm) which are broken up by the drilling operation. The extremely hard finely laminated black shale pieces found in the core catcher of Core 31 are brecciated and fractured (Figure 35). The cracks are filled with halite. According to X-ray diffraction, this black shale is predominantly composed of disordered cristobalite with traces of pyrite and quartz. Under the petrographic microscope (31, CC; Figures 36 a,b,c), angular fragments of cristobalite containing laminated streaks of organic material are cemented by halite. Silica of colloform texture occurs within the halite matrix and forms chains and rings which show undulatory extinction. The texture clearly indicates a colloidal origin. The $2-3 \mathrm{~mm}$ thick 


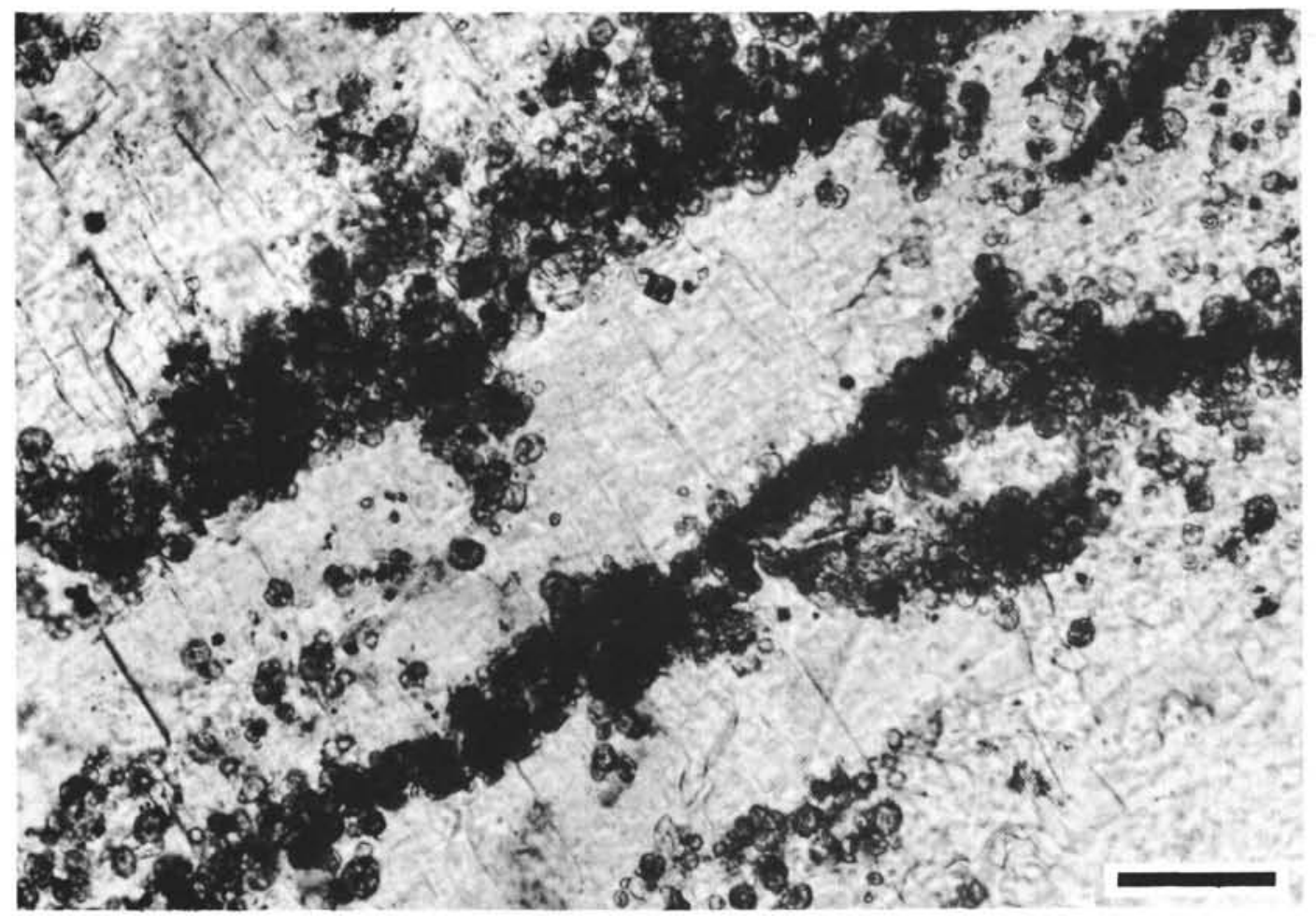

Figure 22. Bedded mosaic anhydrite with thin layers of dolomite impregnated with opaque material (227-37, CC). Scale bar represents $0.1 \mathrm{~mm}$.

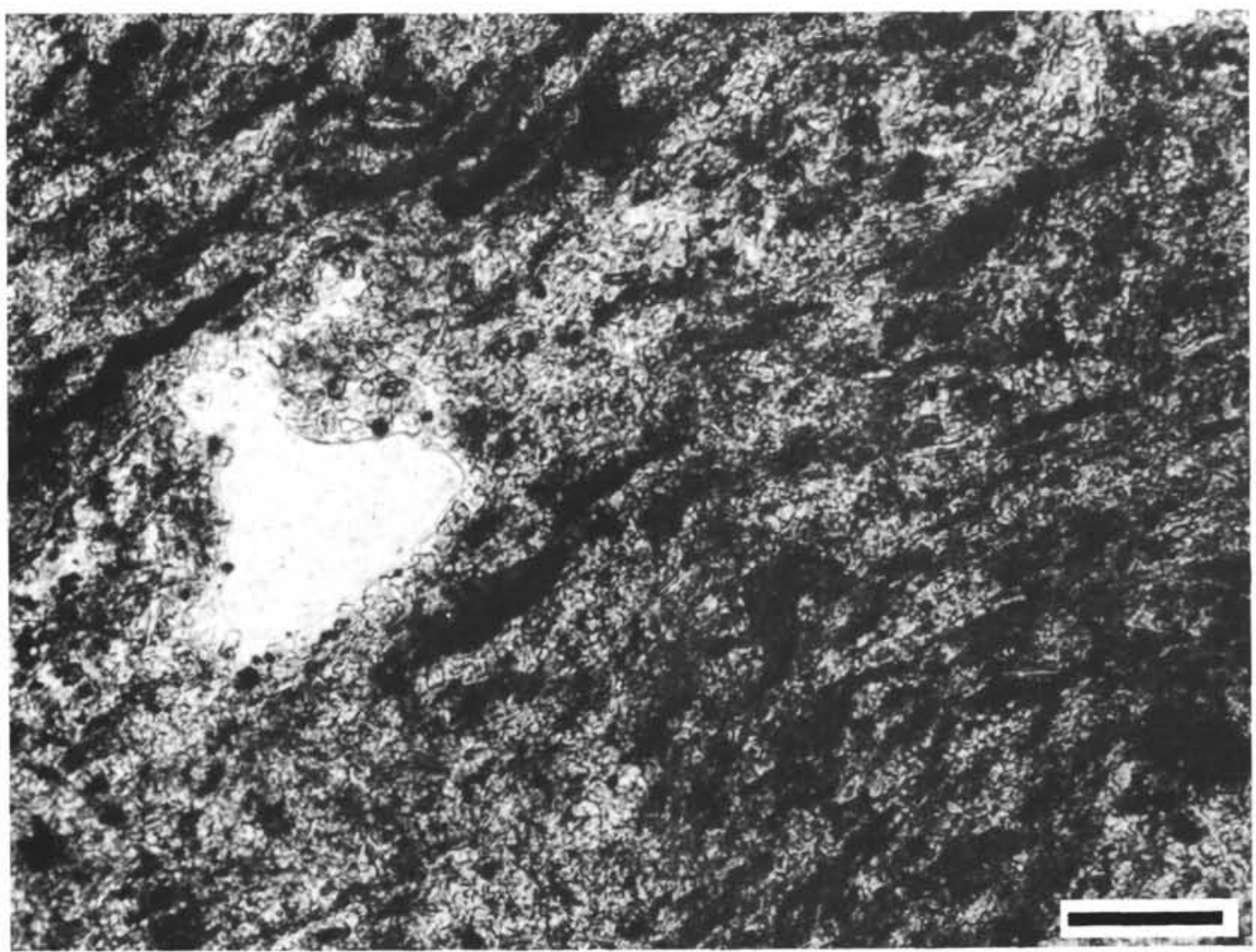

Figure 23. Microcrystalline cristobalite finely laminated by opaque, probably organic rich, material and pyrite (227-36-2). Scale bar represents $0.1 \mathrm{~mm}$. 


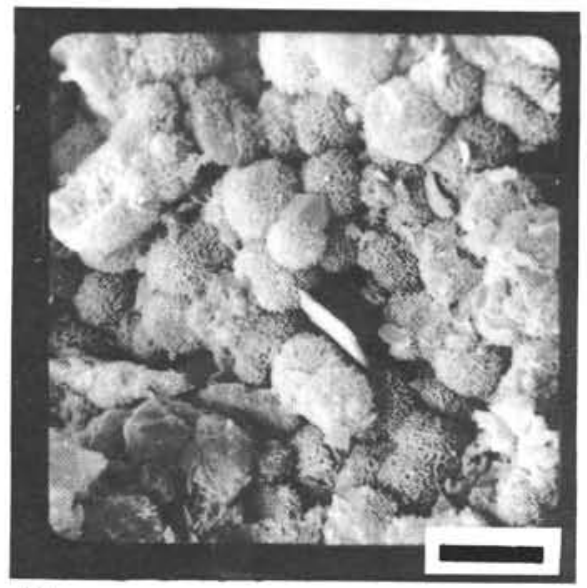

a

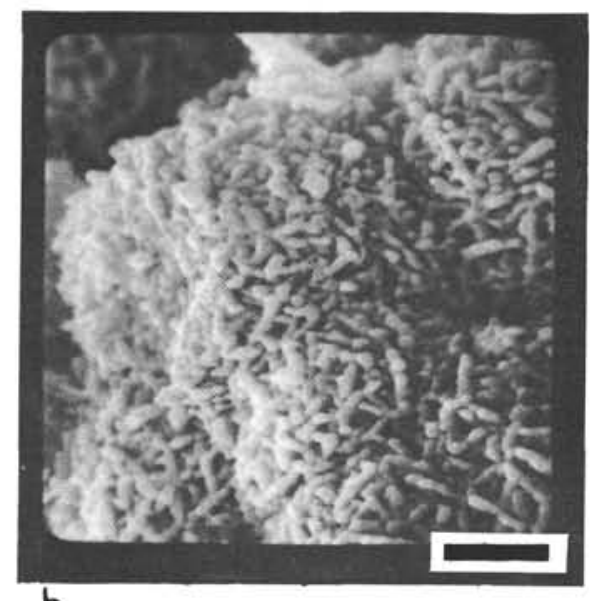

b

Figure 24. Scanning micrographs of cristobalite spherules (227-36-2): (a) scale bar represents $10 \mu$ (micron), and (b) scale bar represents $2 \mu$

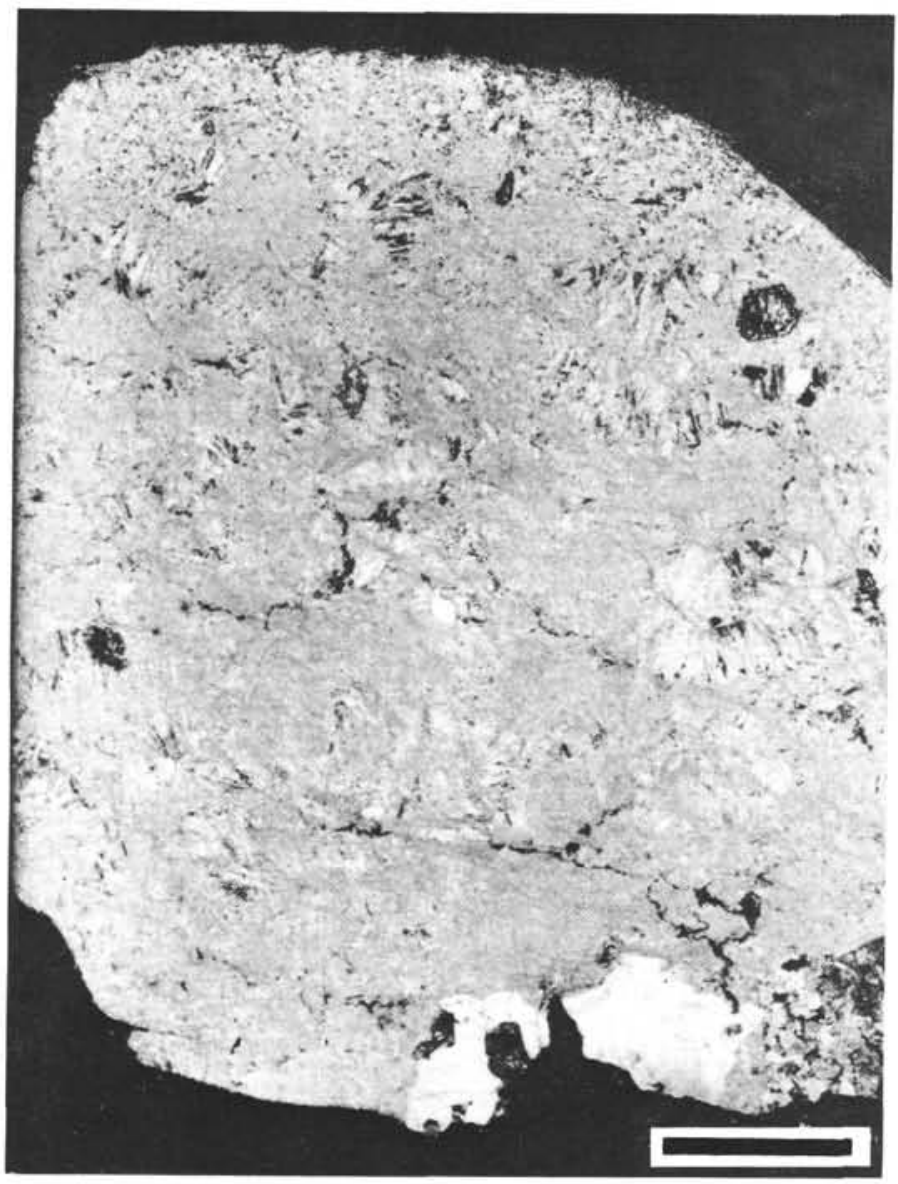

Figure 25. Microcrystalline anhydrite matrix, clusters of coarse crystalline anhydrite and authigenic quartz (227-36$3,5-7 \mathrm{~cm}$ ). Crossed nicols. Scale bar represents $4 \mathrm{~mm}$. 


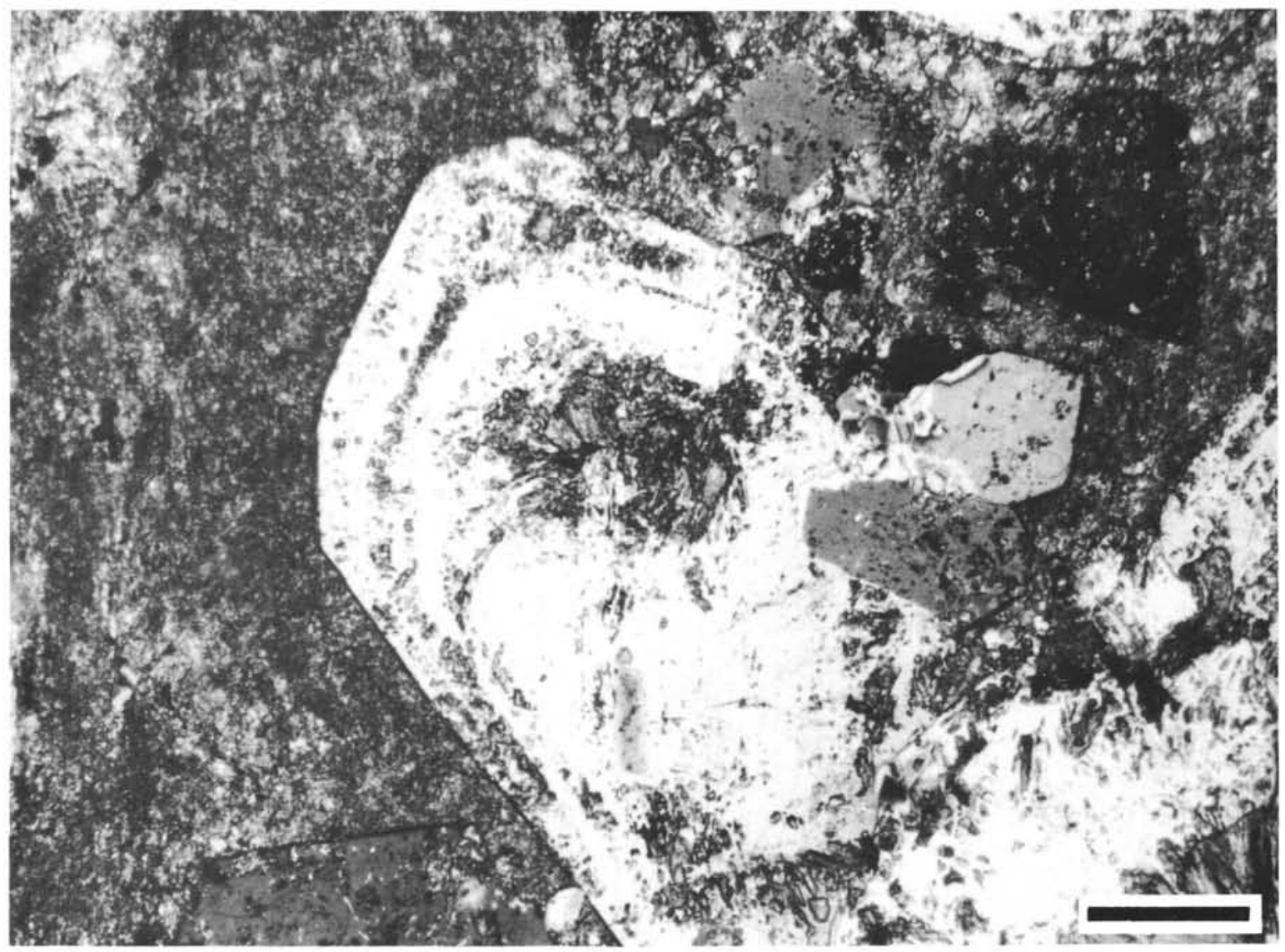

Figure 26. Authigenic quartz with oriented anhydrite inclusions in fine crystalline anhydrite matrix (227-363). Scale bar represents $1 \mathrm{~mm}$. Crossed nicols.

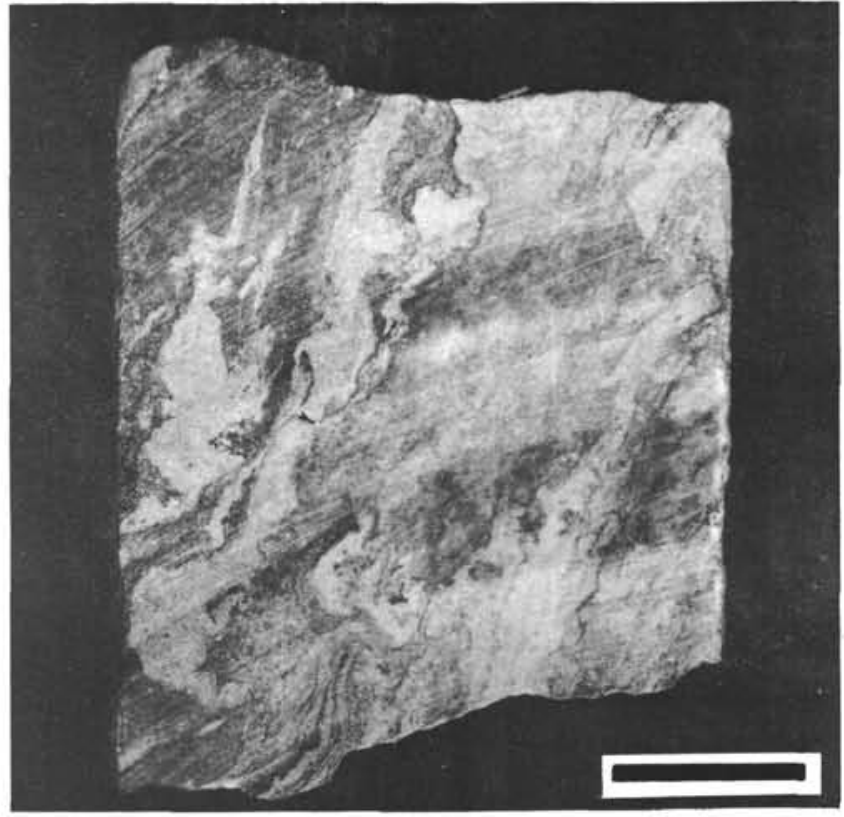

Figure 27. Streaky laminated anhydrite (227-36-2, 73-76 $\mathrm{cm}$ ). Scale bar represents $2 \mathrm{~cm}$. 


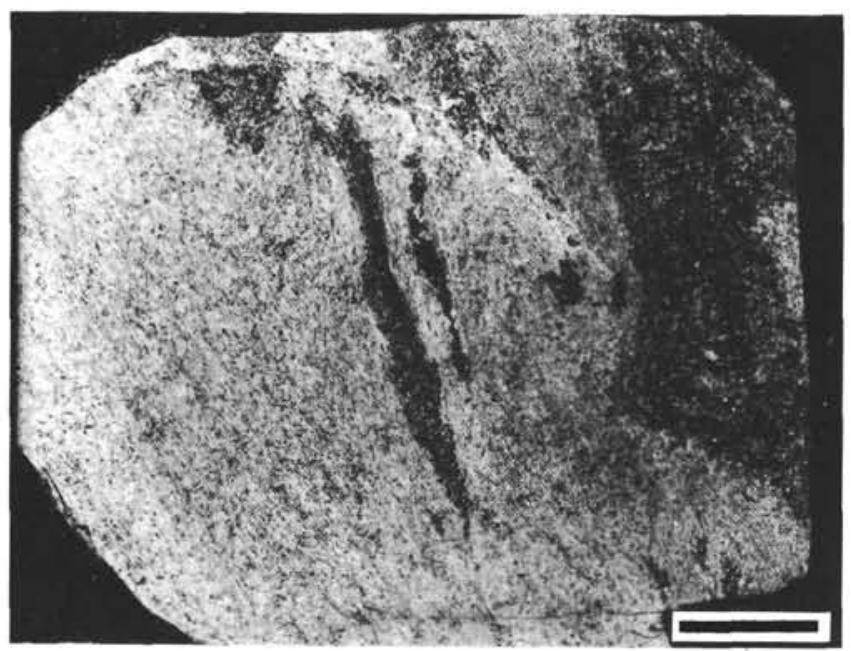

Figure 28. Microcrystalline anhydrite with slightly aligned orientation intercalated with dark fine crystalline magnesite (227-36-2, 73-76 cm). Crossed nicols. Thin section is oriented. Scale bar represents $4 \mathrm{~mm}$.

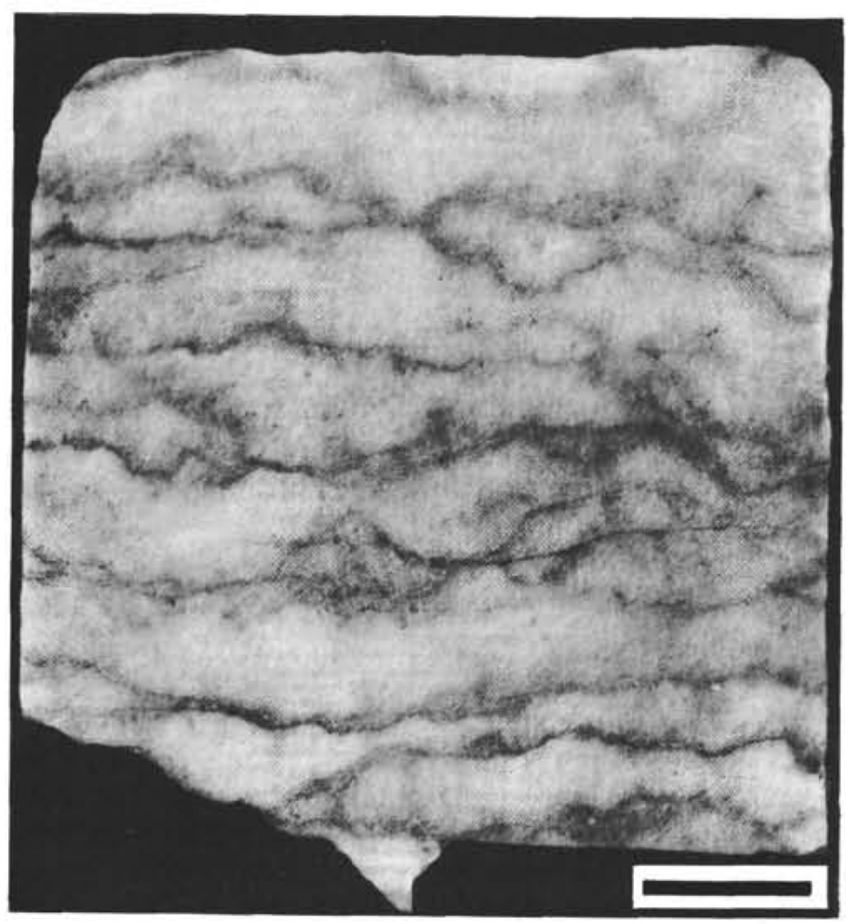

Figure 30. Bedded massive anhydrite (227-35, CC). Scale bar represents $1 \mathrm{~cm}$.

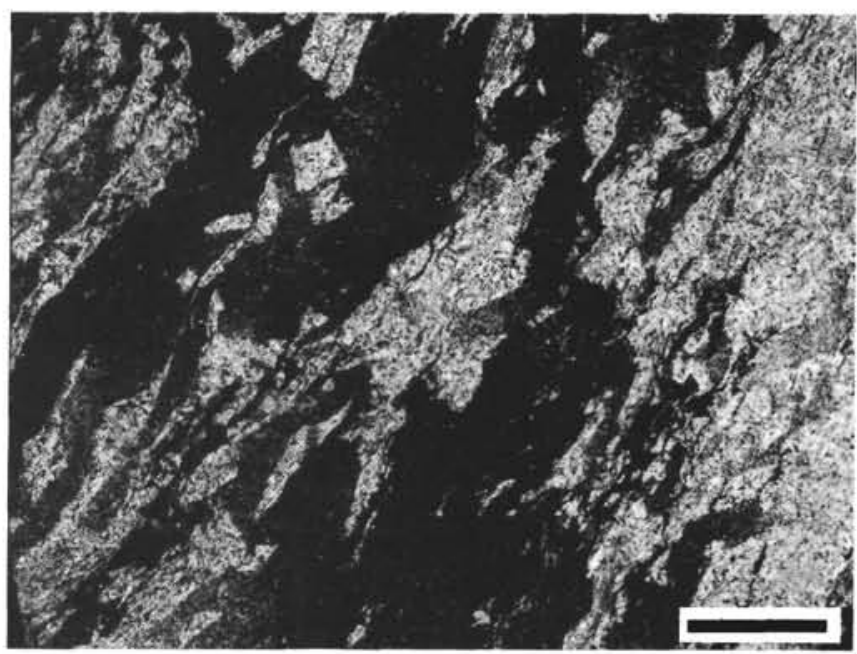

Figure 29. Anhydrite of aligned felted texture. The sharp edges of the anhydrite lumps suggest deformed gypsum pseudomorphs. Dark material is microcrystalline magnesite (227-36-1). Crossed nicols. Scale bar represents $4 \mathrm{~mm}$.

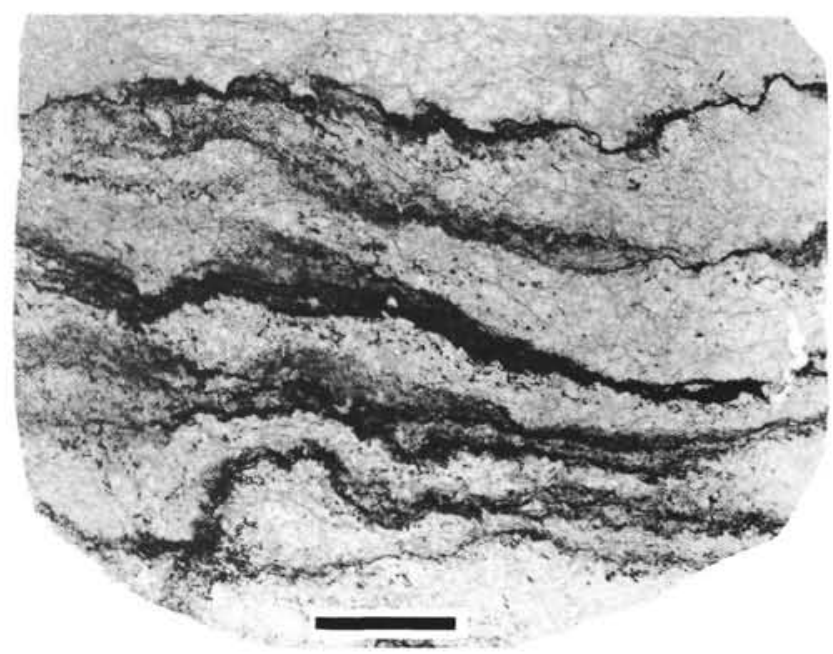

Figure 31. Microcrystalline anhydrite interbedded with dark layers composed of opaque material and small dolomite grains $(227-35-5,115-123 \mathrm{~cm})$. Scale bar represents $4 \mathrm{~mm}$. 
fractured vein, which crosses perpendicular to the bedding plane of the shale, is filled with sheave-like partly radiating bundles of length-slow fibers of quartzine and some megaquartz. The silica of this black shale might be originated from devitrification of volcanic glass or from the dissolution of opaline skeletons. The absence of volcanic alteration products such as clinoptilolite and montmorillonite suggests a biogenic source for the silica. Redeposition of the silica formed disordered cristobalite. Quartzine was precipitated in veins. Due to some kind of tectonic movement, probably caused by salt flowage, the black shale was intensely brecciated. The halite, which filled the cracks, precipitated from the pore solution. Some of the silica was probably dissolved again because of the hypersaline environment and was redeposited within the halite in typically colloform texture. The thin section might demonstrate a diagenetic process leading from probably opaline skeletons via disordered cristobalite and quartzine to megaquartz. The significance of length-slow chalcedony in sedimentary rocks is discussed in great detail by Folk and Pittman (1971). According to these authors, the occurrence of quartzine is characteristic of a silification in highly basic or sulphate-rich environments and is most commonly observed in sequences of shallow-marine or playa lakes and evaporitic, sabkha-type depositions.

X-ray diffraction shows that the dark brown shale fragments in Core 31 consist mainly of dolomite with smaller amounts of layer silicates, quartz, feldspar, pyrite, zeolites, and palygorskite. The white chips found in the shale sequence are completely composed of well-ordered palygorskite. Abundant nannofossils (Discoaster quinqueramus) and rare neritic benthic foraminifera, which occur in the black shale of Core 31 , suggest fluctuations from evaporitic to marine conditions.

The lower part of Core 30, Section $2(100-150 \mathrm{~cm})$ is represented by white halite with thin grayish green anhydrite layers. The overlying rock is bedded massive anhydrite of alternating white $(0.2-0.6 \mathrm{~mm})$ and dark layers (0.02-0.05 mm). Under the petrographic microscope (30-2, $43-48 \mathrm{~cm}$; Figure 37$)$, the anhydrite is of aligned felted texture $(0.015-0.2 \mathrm{~mm})$. The dark brown layers consist of dolomite and micron-sized opaque material.

The anhydrite is topped by dark gray to black semilithified to lithified dolomitic silty claystone (Cores 26-29). The occurrence of nannofossils and foraminifera in Core 26 indicates the change to open marine conditions.

\section{Site 228}

Site 228 lies close to the axial valley of the Red Sea about lat $19^{\circ} \mathrm{N}$ in a water depth of 1038 meters. Three hundred and fifteen meters of sediment was continuously cored, including 35 meters of brecciated anhydrite.

Core 39, Section 1 consists of intensely brecciated anhydrite in a black siltstone matrix (Figure 38). According to X-ray analyses, the siltstone is composed of layer silicates (chlorite and illite, with smaller amounts of mixed layer illite-montmorillonite and kaolinite), anhydrite, quartz, plagioclase, microcline, pyrite, and traces of gypsum. Under the petrographic microscope (39-1, 120-122 $\mathrm{cm}$; 39-1; Figure $39 \mathrm{a,b}$ ), the felted anhydrite crystals $(0.1-0.3 \mathrm{~mm})$ are in random orientation. Dolomite crystals
(0.1-0.3 $\mathrm{mm})$ and authigenic quartz with anhydrite inclusions are scattered in the anhydrite. This siltstone anhydrite breccia is characterized by a high content of heavy metals, especially zinc (Manheim, this volume). The thin section (39-1; Figure 40), in general, shows euhedral sphalerite crystals aligned with the bedding plane. The sphalerite crystals only occur in the anhydrite layers. The brownish, probably organic-rich, semi-opaque layers are free of sphalerite inclusions.

Core 38 is represented by dark greenish gray to dark brown siltstone. Fragments of anhydrite were found in the core catcher. X-ray analyses of siltstone reveal a mineralogy similar to that found in Core 39 . No pyrite and gypsum were detected. Palygorskite is abundant in the greenish material. The dark brown color of the sediments is probably due to amorphous iron. The thin section of the anhydrite (38, CC; Figure 41), in general, shows rounded anhydrite grains $(0.1-0.5 \mathrm{~mm})$ with abundant liquid inclusions. The grains are cemented by pyrite impregnated with carbonate material. The relatively uniform grain size and the scattered occurrence of detrital quartz grains suggest reworked and resedimented anhydrite (Ogniben, 1955).

Core 37, Sections 1 and 2 consist of brecciated anhydrite in a greenish dark siltstone matrix. According to $\mathrm{X}$-ray analyses, the siltstone is composed of layer silicates (illite, illite-montmorillonite and chlorite-montmorillonite mixed layer minerals, kaolinite, and chlorite), quartz, feldspars, and traces of dolomite. In Section 2, palygorskite is locally very abundant. Distorted bedded mosaic anhydrite is found in Section $2(20-35 \mathrm{~cm})$. The thin section (37-1, 145-147 cm; Figure 42) shows felted anhydrite $(\sim 0.05-0.5 \mathrm{~mm})$. The large aggregates surrounded by opaque, probably organic-rich, material seem to indicate gypsum pseudomorphs.

Partly nodular and partly bedded anhydrite with intercalated siltstone $(36-1,108-120 \mathrm{~cm})$ is represented in Core 36, Section 1.

White bedded massive anhydrite $(35-2,125-150 \mathrm{~cm})$ topped by brecciated anhydrite in a black siltstone matrix and black siltstone $(35-2,0-125 \mathrm{~cm})$ is found in Core 35 . Under the petrographic microscope, the lath-shaped anhydrite crystals $(\sim 1-1.5 \mathrm{~mm})$ are oriented parallel to the bedding plane $(35-2,120-125 \mathrm{~cm}$; Figure 43$)$. Salt tectonics is suggested by the fractured and bent anhydrite layers (35-2, 116-117 cm; Figure 44). The thin section (35-2, $116-117 \mathrm{~cm}$; Figure 45) shows anhydrite of microcrystalline texture $(\sim 0.01 \mathrm{~mm})$. The thin dark layers, which are about $0.5 \mathrm{~mm}$ apart, consist of opaque, probably organicrich, material, pyrite, and some tiny dolomite crystals. Bedded massive anhydrite is found at the top of Core 35, Section 2 (35-2, 14-17 cm; Figure 46). Darker layers of coarse-grained material are intercalated in the anhydrite. Under the petrographic microscope $(35-2,14-17 \mathrm{~cm}$; Figure $47)$, the anhydrite is of microcrystalline texture $(\sim 0.01$ $\mathrm{mm}$ ) and shows bedding due to the intercalated thin opaque layers. Abundant clastic material is interspersed in the anhydrite. The clastic material is generally rounded to angular and consists of quartz, feldspar, and heavy minerals (green hornblende and epidote). In the upper part of the section, the clastic material is fine grained $(\sim 0.1 \mathrm{~mm})$, 


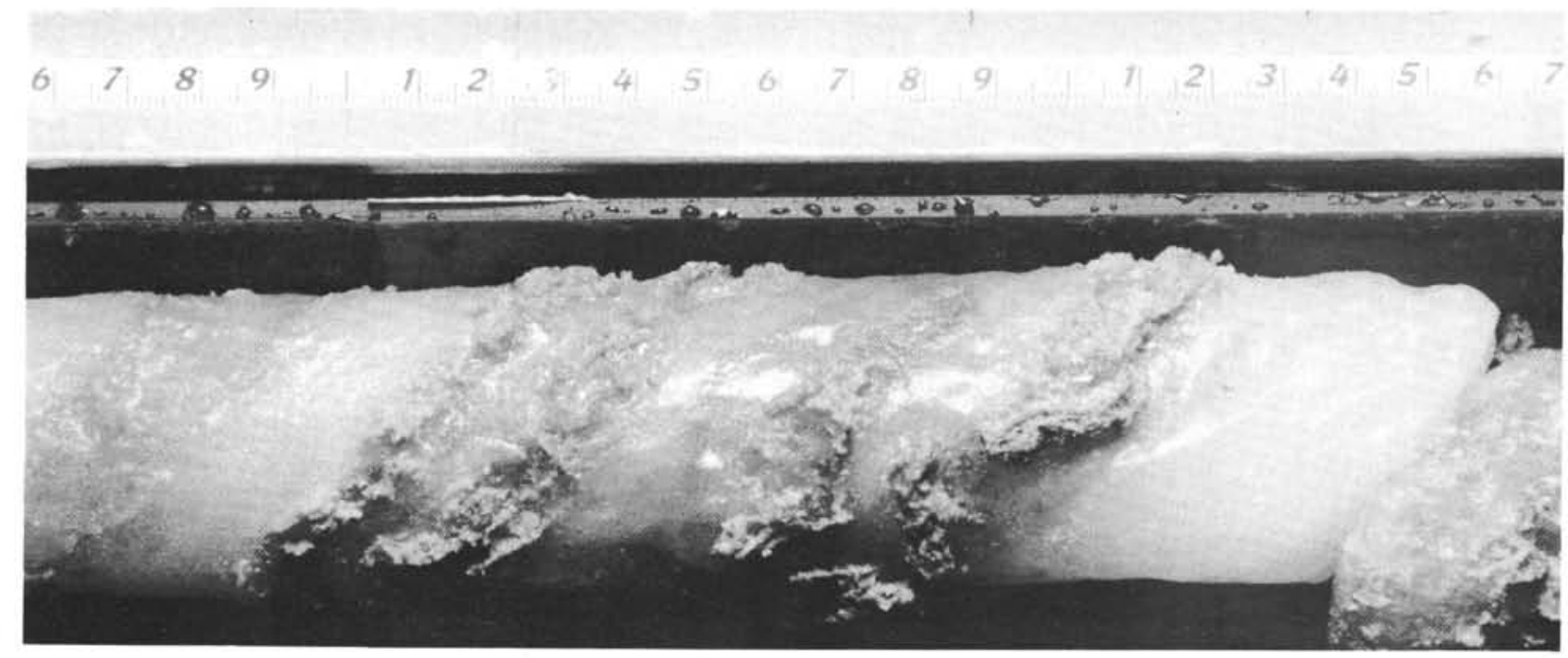

Figure 32. Alternating clear white and gray halite with intercalated thin anhydrite layers (227-35-4).

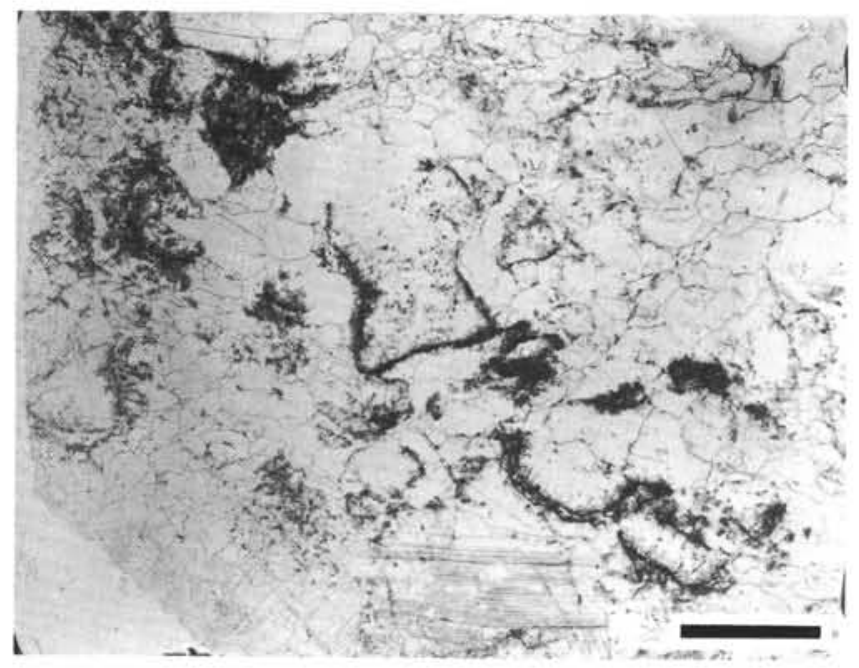

Figure 33. Coarse crystalline halite with clusters and streaks of lath-shaped anhydrite $(227-35-3,53-60 \mathrm{~cm})$. Scale bar represents $4 \mathrm{~mm}$.

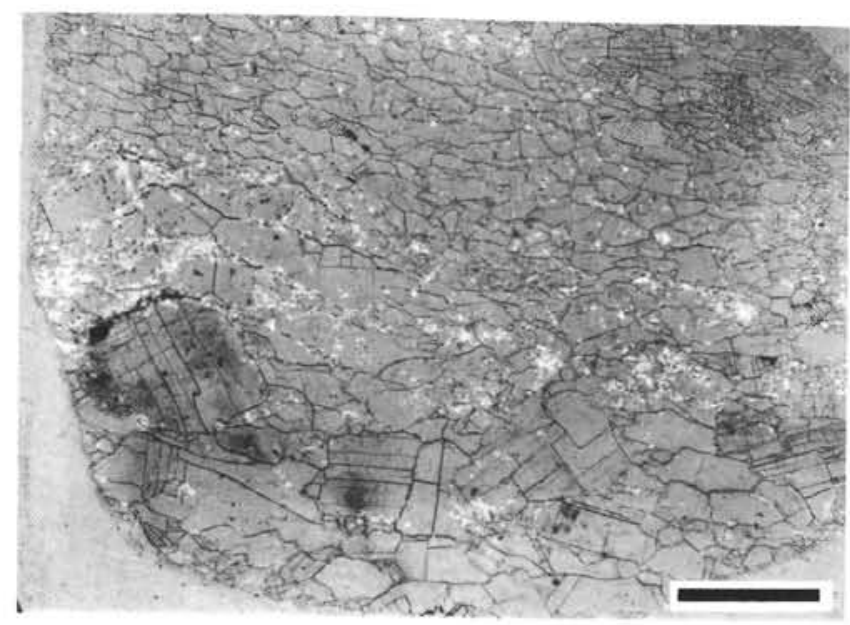

Figure 34. Coarse crystalline mosaic halite with interspersed polyhalite $(227-33-1,80-84 \mathrm{~cm})$. Partially crossed nicols. Scale bar represents $4 \mathrm{~mm}$.

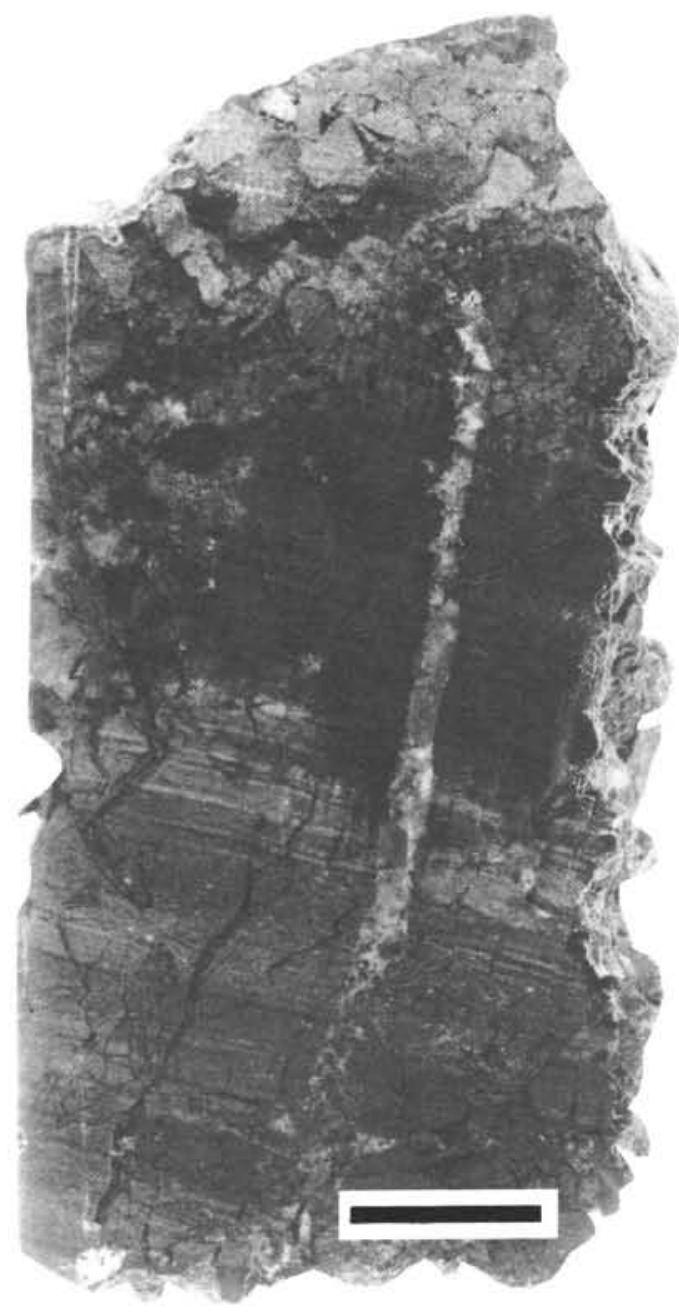

Figure 35. Fractured laminated black shale with a chalcedony filled vein (227-31, CC). Scale bar represents $1.25 \mathrm{~cm}$. 

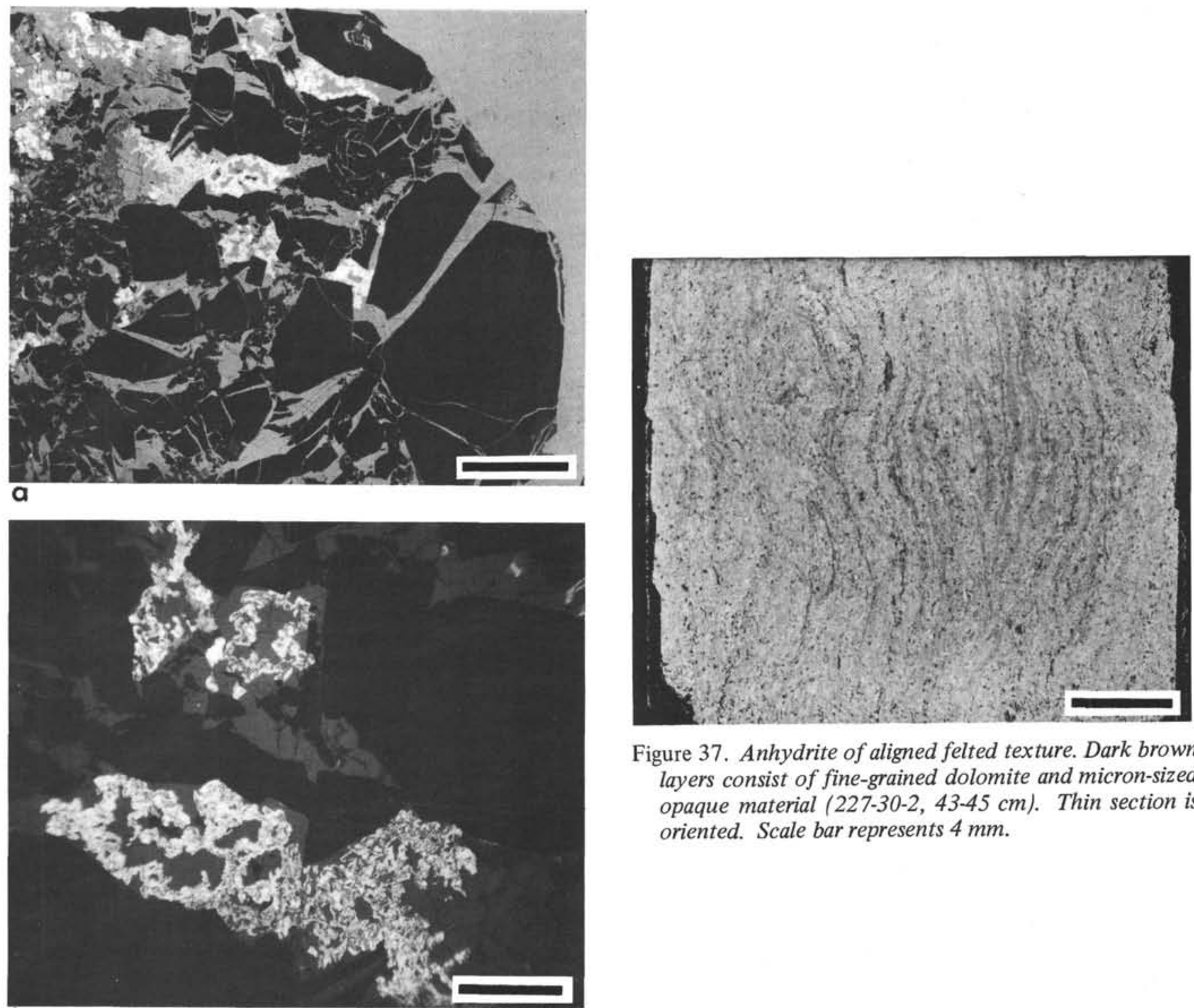

Figure 37. Anhydrite of aligned felted texture. Dark brown layers consist of fine-grained dolomite and micron-sized opaque material $(227-30-2,43-45 \mathrm{~cm})$. Thin section is oriented. Scale bar represents $4 \mathrm{~mm}$.

b

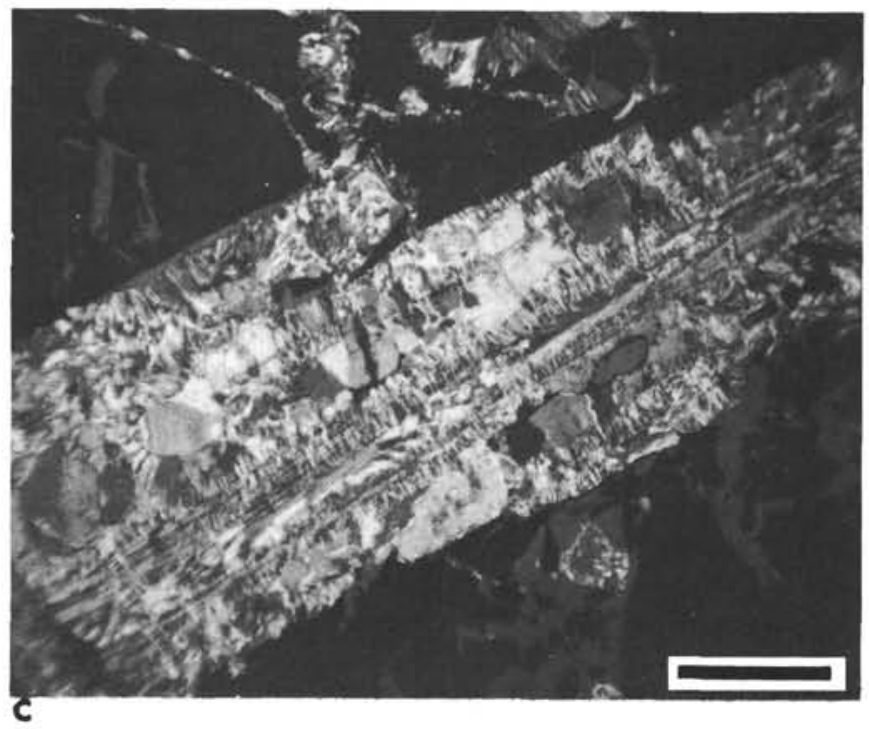

Figure 36. Fractured cristobalitic shale, cracks are filled with halite, colloform silica is within the halite. (227-31, CC): (a) scale bar represents $4 \mathrm{~mm}$; partially crossed nicols, (b) scale bar represents $\sim 1 \mathrm{~mm}$; partially crossed nicols, and (c) fractured length-slow chalcedony vein with megaquartz; scale bar represents $\sim 1 \mathrm{~mm}$; partially crossed nicols. 


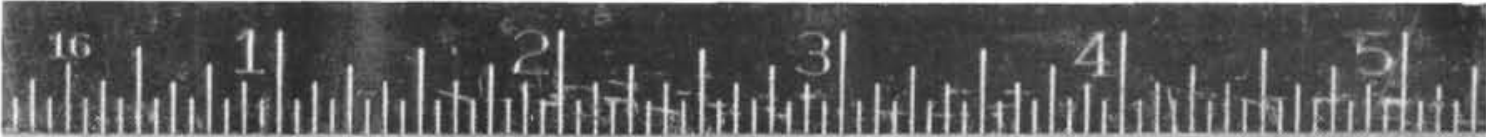

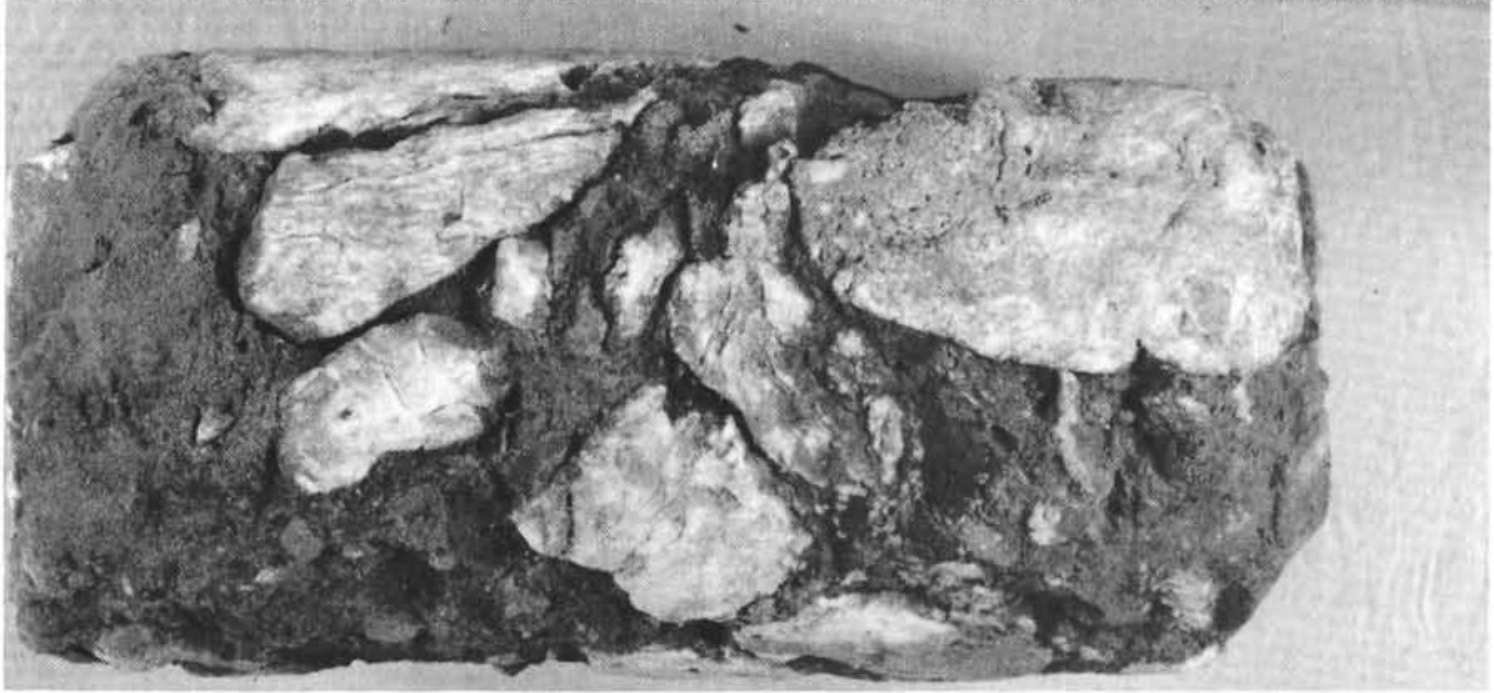

Figure 38. Intensely brecciated anhydrite in a black siltstone matrix.
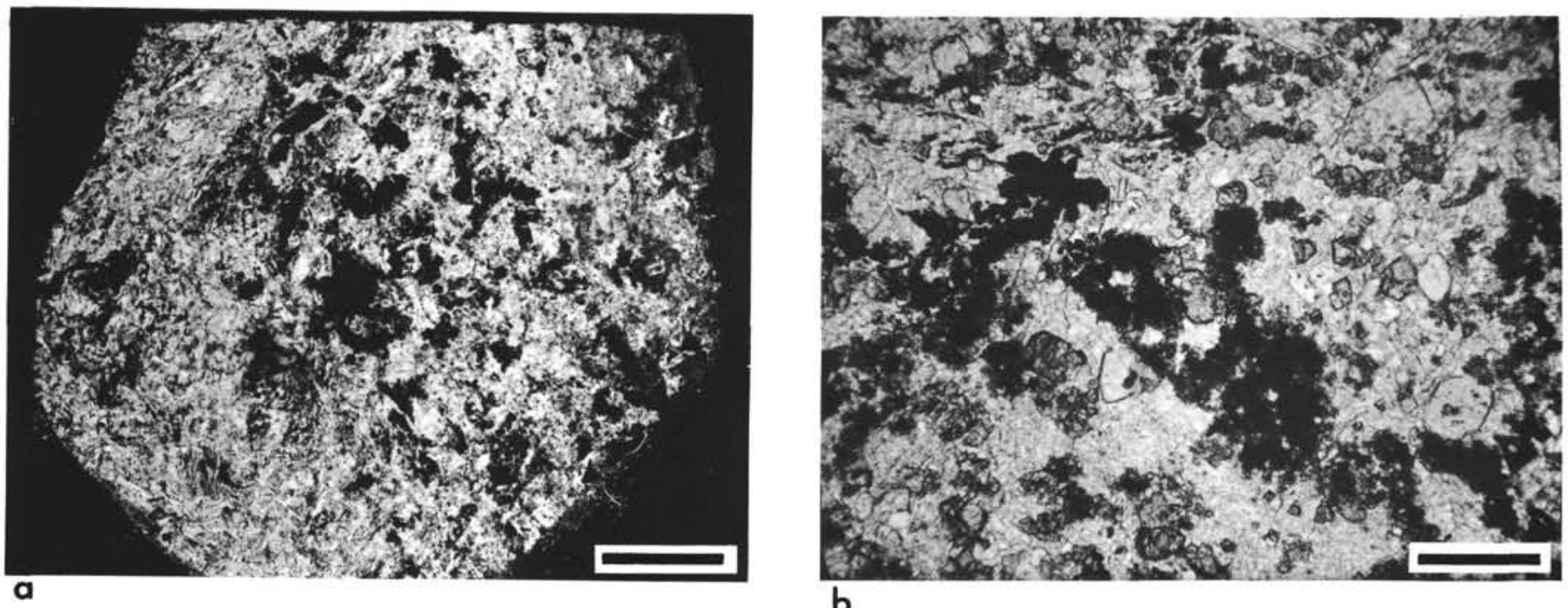

b

Figure 39. Felted anhydrite crystals with dolomite and authigenic quartz $(228-39-1,120-122 \mathrm{~cm})$ : (a) scale bar $4 \mathrm{~mm}$; crossed nicols; and (b) scale bar $0.5 \mathrm{~mm}$. 


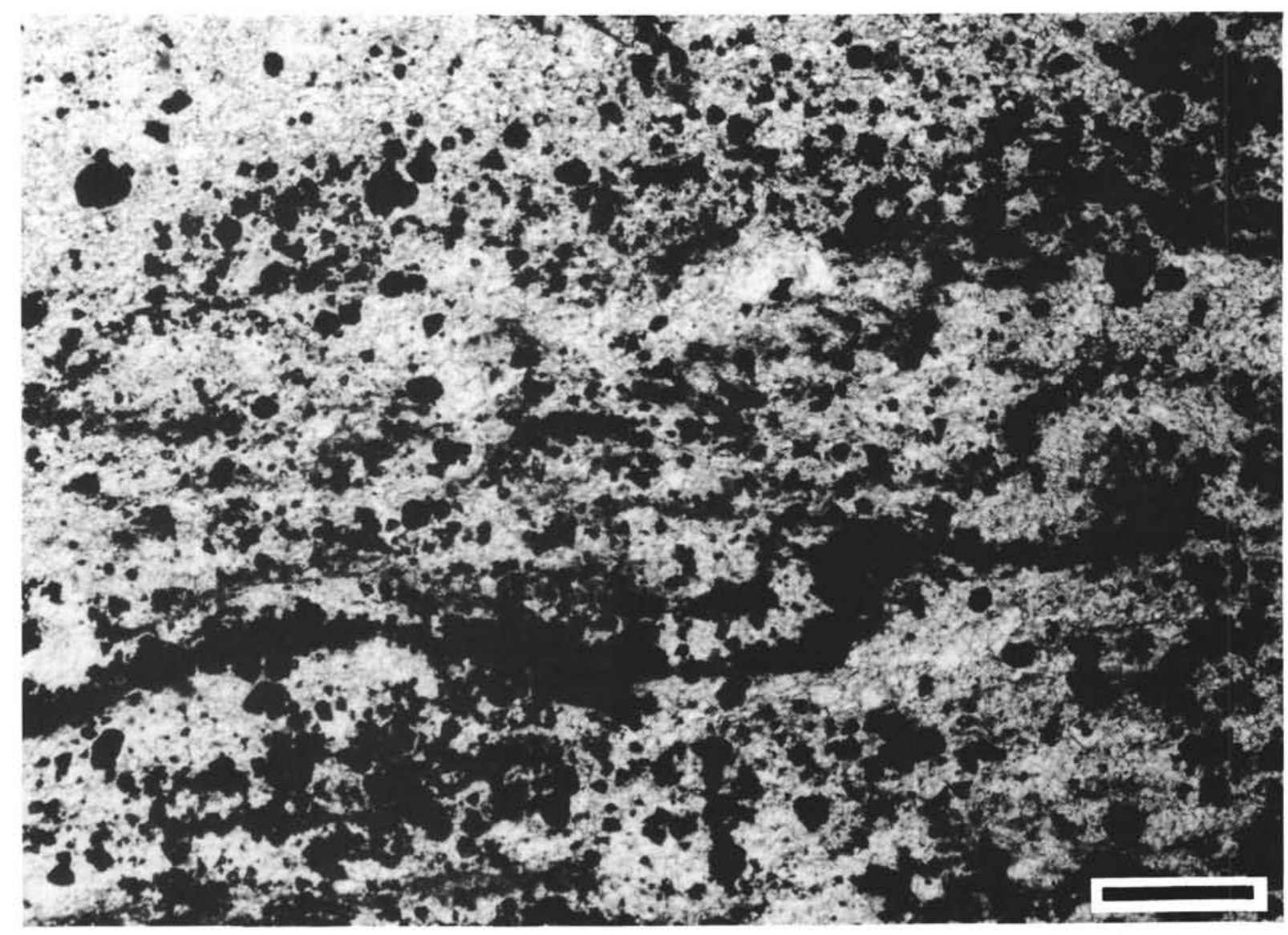

Figure 40. Sphalerite and pyrite crystals in anhydrite (228-39-1). Scale bar represents $0.4 \mathrm{~mm}$.

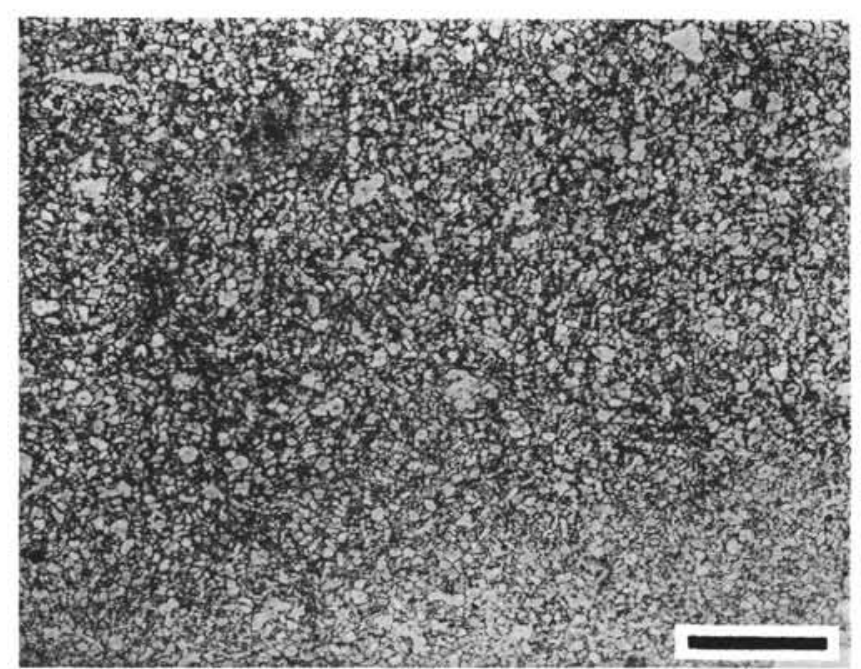

Figure 41. Rounded anhydrite grains cemented by pyrite and some dolomite grains $(228-38, C C)$. Scale bar represents $4 \mathrm{~mm}$.

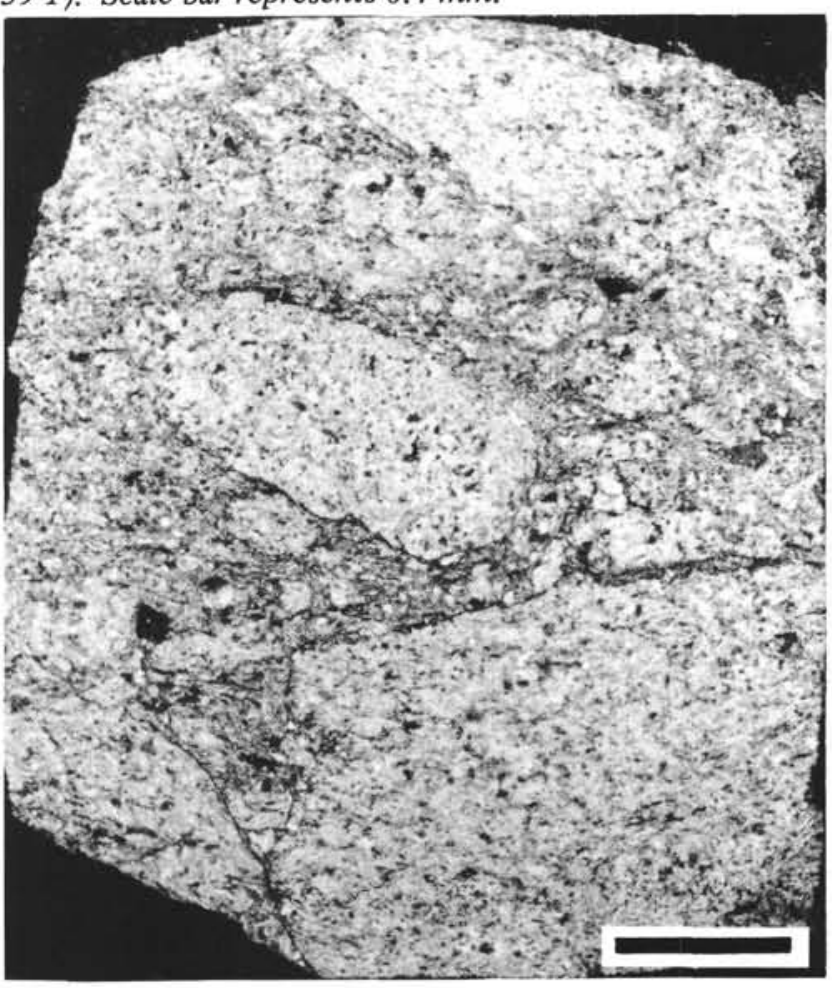

Figure 42. Felted anhydrite. Large aggregates seem to indicate gypsum pseudo-morphs $(228-37-1,145-147 \mathrm{~cm})$. Crossed nicols. Thin section is oriented. Scale bar represents $4 \mathrm{~mm}$. 


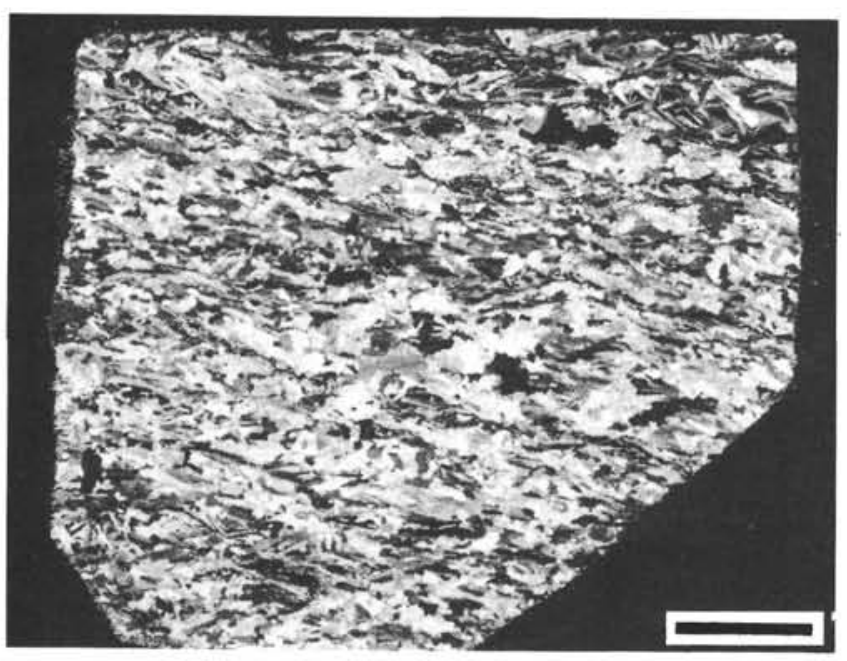

Figure 43. Lath-shaped anhydrite crystals oriented parallel to the bedding plane $(228-35-2,120-125 \mathrm{~cm})$. Crossed nicols. Thin section is oriented. Scale bar represents 4 $\mathrm{mm}$.

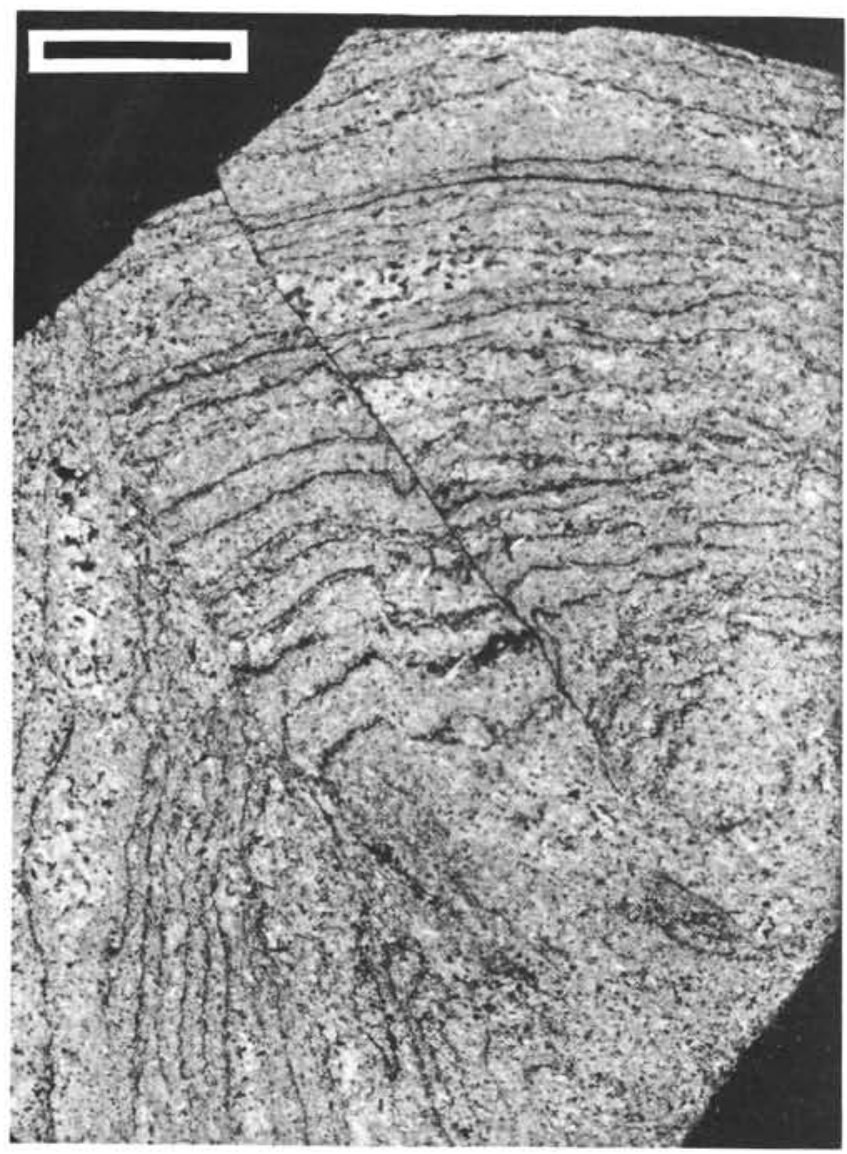

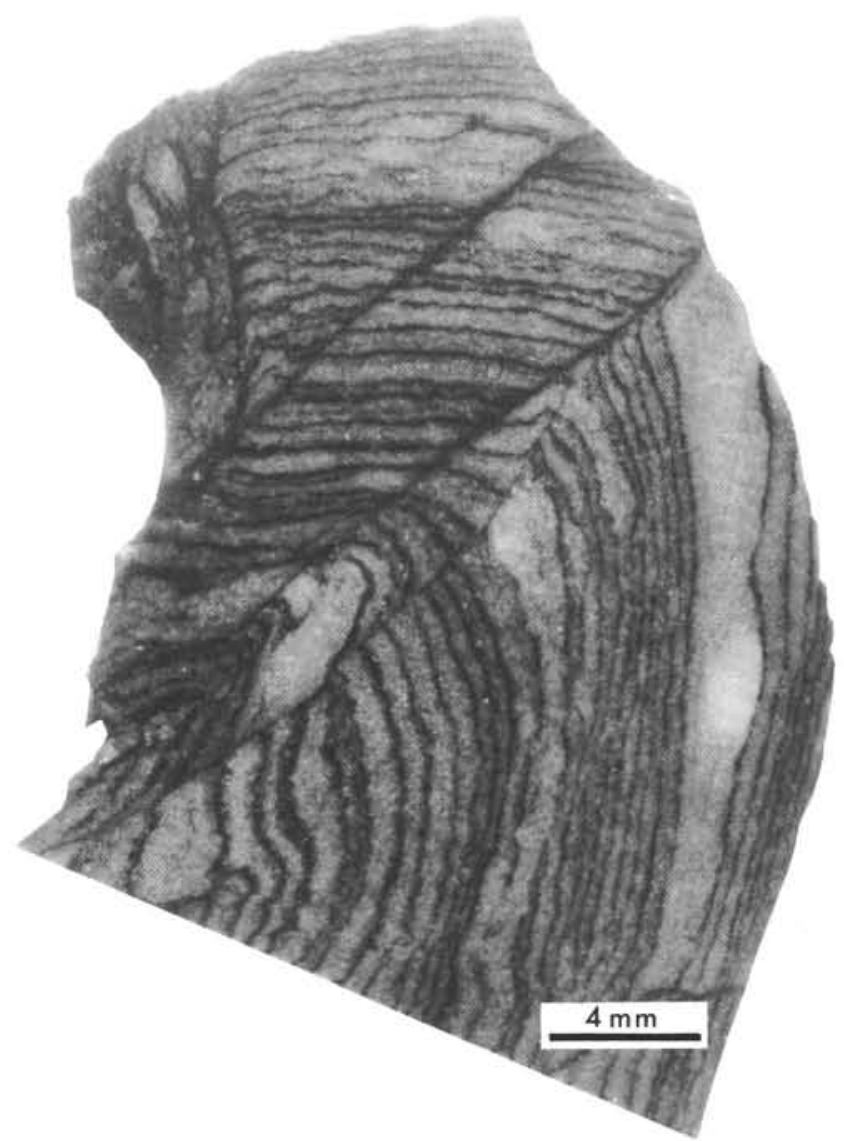

Figure 44. Fractured and bent massive anhydrite layers $(228-35-2,116-117 \mathrm{~cm})$. Scale bar represents $4 \mathrm{~mm}$.

Figure 45. Microcrystalline anhydrite. Dark layers consist of opaque material, pyrite and small dolomite crystals (228-35-2, 116-117 cm). Crossed nicols. Scale bar represents $4 \mathrm{~mm}$. 
whereas, the grain size in the lower section is about $0.5 \mathrm{~m}$ which suggests graded bedding. Medium gray distorted bedded to nodular mosaic anhydrite occurs at the bottom of Core 35, Section 1. Frequently, the anhydrite masses are separated by a dark matrix. The thin section (35-1, 133-135 $\mathrm{cm}$; Figure 48) shows anhydrite of aligned felted texture. The bedded character is demonstrated by intercalated layers of opaque and clastic material (quartz, feldspar) $(\sim 0.07 \mathrm{~mm})$. According to X-ray analyses, the shales of Section 1 are composed of layer silicates, quartz, feldspar, clinoptilolite, pyrite, and traces of dolomite. The clay fraction is dominated by montmorillonite and smaller amounts of chlorite and illite. Palygorskite is locally abundant.

As in Sites 225 and 227, the evaporites of Site 228 are topped by a semilithified black dolomitic silty claystone. Marine fossils first occur in Core 33 and increase towards the top of the hole, thus indicating the change to open marine conditions.

\section{GEOCHEMICAL STUDIES}

\section{Introduction}

Basic research concerning the geochemistry of evaporites was carried out by Van't Hoff and coworkers (1912). Since then, geochemical studies, of trace elements in particular, have gained increasing significance. Bromine, strontium, and rubidium are of special interest for the study of halite, anhydrite/gypsum, and potash deposits, respectively.

\section{Methods}

\section{Bromine (Br) and Rubidium ( $\mathrm{Rb})$}

For the $\mathrm{Br}$ determination, the analytical method described by D'Ans and Höfer (1934) was used. Approximately $10 \mathrm{~g}$ of sample was dissolved and buffered with phosphate solution, oxidized with $\mathrm{NaOCl}$, and the bromate titrated with $\mathrm{n} / 100$ thiosulfate solution after the addition of $\mathrm{K}$ solution. No other chloridic mineral was detected under the petrographic microscope. $\mathrm{Cl}$ was determined according to the Mohr method $\left(\mathrm{AgNO}_{3}\right)$ and the $\mathrm{Br}$ data could be referred to pure halite.

Potassium was detected flame photometrically and $\mathrm{Rb}$ by atomic absorption spectrophotometer. Under the petrographic microscope, polyhalite was determined as the only potassium salt. Therefore, the $\mathrm{K}$ content was referred to polyhalite. $\mathrm{Rb}$ was detected in two samples which have a relatively high polyhalite content. The $R b$ values were referred to pure polyhalite. Results are given in Table 1.

\section{Strontium (Sr) and Calcium (Ca)}

Analyses were carried out to determine the $\mathrm{Sr}$ and $\mathrm{Ca}$ content of the anhydrite samples as well as the anhydrite obtained as "water insoluble residue" from one of the halite samples. $1 \mathrm{~g}$ of sample was dissolved in 1 liter of water with the addition of $\mathrm{HCl}$ and $\mathrm{La}_{2} \mathrm{O}_{3}$ and the $\mathrm{Sr}$ measured by atomic absorption spectrophotometry.

Ca was determined titrimetrically by means of Titriplex III $\left(\mathrm{C}_{10} \mathrm{H}_{14} \mathrm{~N}_{2} \mathrm{Na}_{2} \mathrm{O}_{8} 2 \mathrm{H}_{2} \mathrm{O}\right)$. In most samples, anhydrite was the only $\mathrm{Ca}$ mineral detected under the petrographic microscope; thus, the $\mathrm{Ca}$ could be considered as anhydrite and the $\mathrm{Sr}$ be referred to it. Carbonate minerals (dolomite and magnesite) were found in four samples. $\mathrm{SO}_{4}$ was determined gravimetrically as $\mathrm{BaSO}_{4}$ in these samples.
TABLE 1

Analyses of Halite Samples from Sites 225 and 227

\begin{tabular}{|c|c|c|c|}
\hline Sample & $\begin{array}{c}\mathrm{NaCl} \\
(\%)\end{array}$ & $\begin{array}{c}\text { Polyhalite } \\
\left(2 \mathrm{CaSO}_{4} \mathrm{MgSO}_{4}\right. \\
\left.\mathrm{K}_{2} \mathrm{SO}_{4} 2 \mathrm{H}_{2} \mathrm{O}\right) \\
(\%)\end{array}$ & $\begin{array}{c}\text { Br per pure } \\
\mathrm{NaCl} \\
(\%)\end{array}$ \\
\hline \multicolumn{4}{|l|}{ Site 225} \\
\hline $\begin{array}{l}27-2,110-112 \\
28-1,100-105 \\
28-3,95-105 \text { (top) } \\
28-3,95-105 \text { (bottom) } \\
29-2,125-130 \\
29-3,40-45 \text { (top) }^{\mathrm{a}} \\
29-3,40-45 \text { (bottom) } \\
29-3,100-103\end{array}$ & $\begin{array}{l}98.85 \\
99.28 \\
84.33 \\
99.33 \\
95.33 \\
73.91 \\
85.78 \\
89.44\end{array}$ & $\begin{array}{r}0.16 \\
0.16 \\
0.16 \\
0.08 \\
3.52 \\
25.56 \\
14.07 \\
1.56\end{array}$ & $\begin{array}{l}0.0061 \\
0.0059 \\
0.0049 \\
0.0055 \\
0.0126 \\
0.0137 \\
0.0128 \\
0.0129\end{array}$ \\
\hline \multicolumn{4}{|l|}{ Site 227} \\
\hline $\begin{array}{l}30-2,97-101 \\
30-2,120-124 \\
32-2,135-140 \\
32-5,80-85 \\
33-1,80-84 \\
33-1,130-133 \\
33-2,100-105 \\
34-2,77-80 \\
35-1,143-150 \text { (top) } \\
35-1,143-150 \text { (medium) }\end{array}$ & $\begin{array}{l}97.35 \\
94.55 \\
95.16 \\
98.90 \\
98.81 \\
97.02 \\
99.10 \\
98.44 \\
99.27 \\
96.74\end{array}$ & $\begin{array}{l}0.16 \\
0.16 \\
3.52 \\
1.29 \\
1.25 \\
2.75 \\
1.15 \\
0.36 \\
0.06 \\
0.06\end{array}$ & $\begin{array}{l}0.0035 \\
0.0124 \\
0.0161 \\
0.0160 \\
0.0167 \\
0.0165 \\
0.0159 \\
0.0141 \\
0.0097 \\
0.0093\end{array}$ \\
\hline $\begin{array}{l}35-1,143-150 \text { (bottom) } \\
35-3,53-60 \\
35-5,115-123 \\
41-1, \sim 105-110 \\
42-1,100-103 \\
42-2,125-130 \\
43-2,20-25 \text { (top) } \\
43-2,20-25 \text { (bottom) } \\
43-5,128-136 \\
45-1,75-80 \text { b } \\
45-1,112-117\end{array}$ & $\begin{array}{l}97.80 \\
93.81 \\
36.79 \\
98.22 \\
99.84 \\
94.98 \\
98.90 \\
97.59 \\
91.63 \\
90.79 \\
92.80\end{array}$ & $\begin{array}{l}0.06 \\
0.00 \\
0.16 \\
0.04 \\
0.16 \\
0.38 \\
0.08 \\
0.16 \\
0.00 \\
8.77 \\
7.16\end{array}$ & $\begin{array}{l}0.0094 \\
0.0085 \\
0.0060 \\
0.0084 \\
0.0083 \\
0.0078 \\
0.0072 \\
0.0069 \\
0.0054 \\
0.0132 \\
0.0098\end{array}$ \\
\hline
\end{tabular}

Note: All values given in weight-\%.

${ }^{\mathrm{a}} \mathrm{Rb}$ content is 0.00037 weight $\%$ per total sample or 0.0014 weight $-\% \mathrm{Rb}$ per pure polyhalite.

${ }^{\mathrm{b}} \mathrm{Rb}$ content is 0.00013 weight $-\%$ per total sample or 0.0014 weight $-\% \mathrm{Rb}$ per pure polyhalite.

Anhydrite was calculated on the basis of $\mathrm{SO}_{4}$ while the $\mathrm{Ca}$ excess was bound as $\mathrm{CaCO}_{3}$. Results are given in Table 2 .

\section{Results}

\section{Bromine (Br)}

The use of bromine as a geochemical indicator of the marine evaporite environment has been discussed in a number of publications (Boeke, 1908; D'Ans and Kühn, 1940; Kühn, 1953, 1955; Braitsch and Herrmann, 1962, 1963; Valyashcko, 1956; Holser, 1966a; Wardlaw and Schwerdtner, 1966; Herrmann, 1972; etc.). Bromine values can be used to indicate the relative balance between influx and reflux into or out of the basin. Fairly constant bromine values during salt deposition suggest that the salinity of the basin brines remained constant. Bromine profiles which show an increase in the bromine content during salt deposition indicate a reduced influx or reflux which correspond to a higher salinity of the basin brine. Decreasing bromine content points to increasing influx or reflux which lowered the salinity of the brines in the basin. 
P. STOFFERS, R. KÜHN

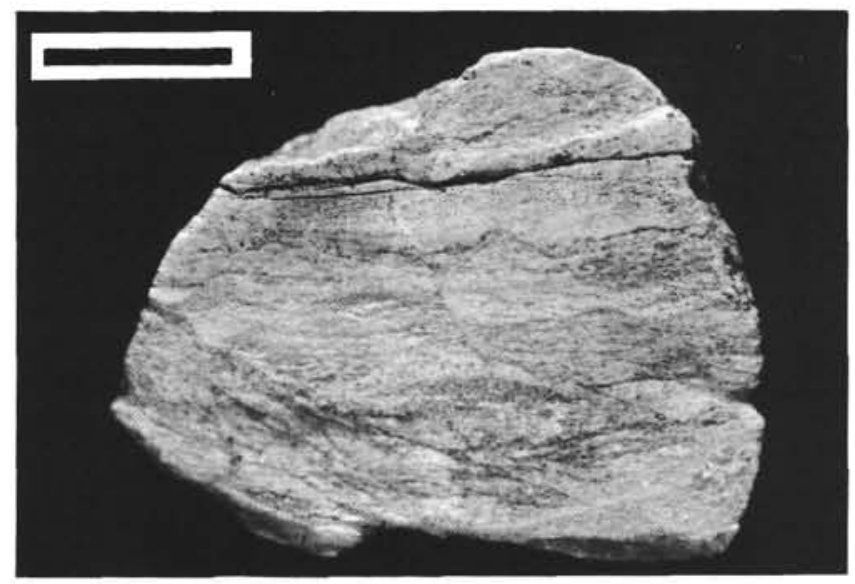

Figure 46. Bedded massive anhydrite with layers of clastic material (228-35-2, 14-17 cm). Scale bar represents $2 \mathrm{~cm}$.

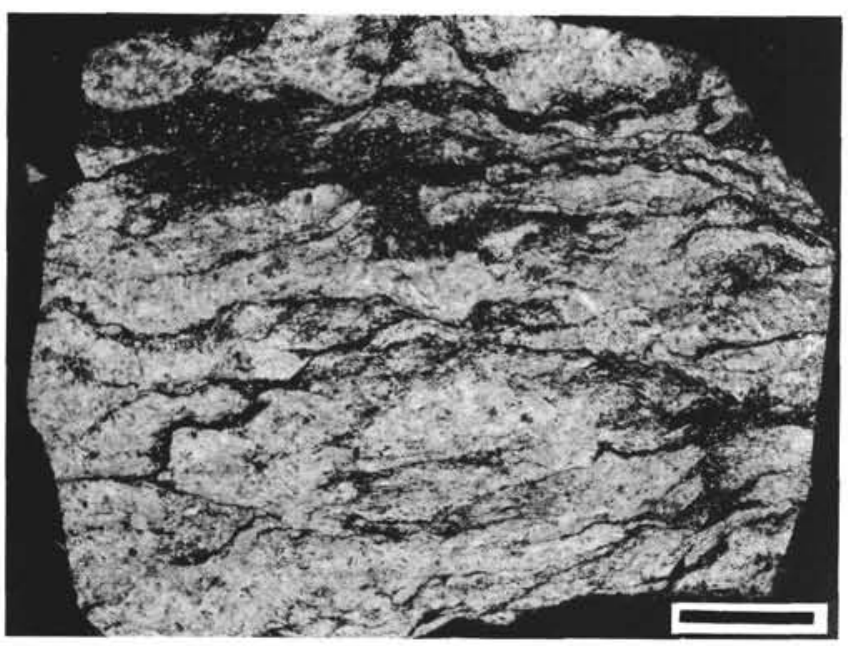

Figure 47. Microcrystalline anhydrite intercalated with angular clastic material. Clastic material shows grading (228-35-2, 14-17 cm). Crossed nicols. Thin section is oriented. Scale bar represents $4 \mathrm{~mm}$.

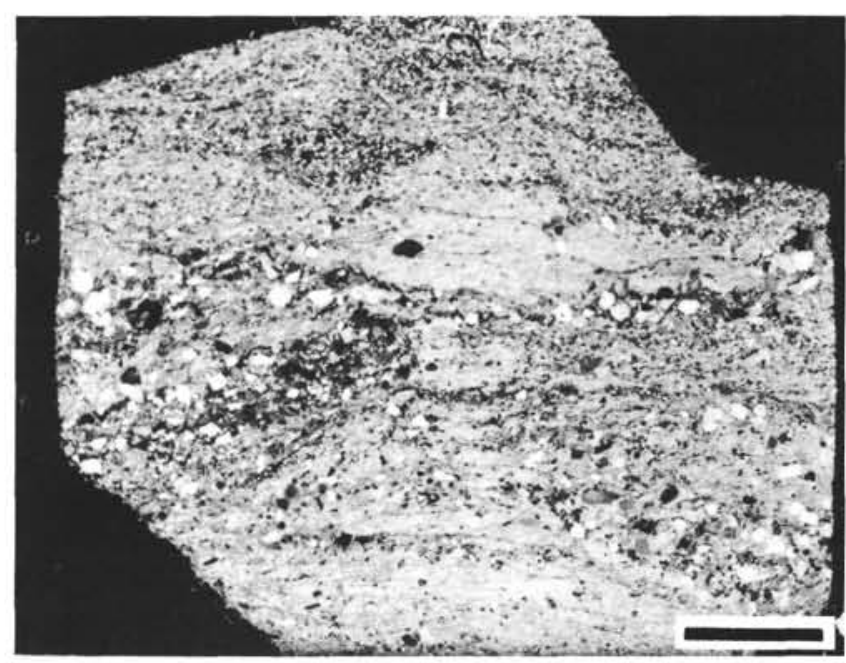

Figure 48. Anhydrite of aligned felted texture with intercalated opaque, probably organic-rich, material and clastic detritus (228-35-1, 133-135 cm). Crossed nicols. Thin section is oriented. Scale bar represents $4 \mathrm{~mm}$. 
TABLE 2

Analyses of Anhydrite Samples

\begin{tabular}{|c|c|c|c|c|c|}
\hline Sample & $\begin{array}{c}\mathrm{CaSO}_{4} \\
(\%)\end{array}$ & $\begin{array}{c}\mathrm{CaCO}_{3} \\
(\%)\end{array}$ & $\begin{array}{l}\mathrm{Sr} \\
(\%)\end{array}$ & $\frac{\mathrm{Sr} \cdot 1000}{\mathrm{Ca}}$ & $\begin{array}{c}\text { Sr per pure } \\
\text { anhydrite } \\
(\%)\end{array}$ \\
\hline $225-24-1,70-74$ & 96.87 & - & 0.099 & 3.47 & 0.102 \\
\hline $225-24-1,80-85$ & 98.21 & - & 0.159 & 5.50 & 0.162 \\
\hline $225-26-1,140-144$ & 99.84 & - & 0.166 & 5.65 & 0.166 \\
\hline $225-26-2,133-136$ & 99.50 & - & 0.170 & 5.80 & 0.170 \\
\hline $225-27-1,119-122$ & 96.51 & - & 0.195 & 6.86 & 0.203 \\
\hline $225-27-2,85-87$ & 98.67 & - & 0.243 & 8.36 & 0.246 \\
\hline $225-29-1,133-136$ & 100.20 & - & 0.235 & 7.90 & 0.230 \\
\hline $225-29-2,10-20$ & 99.33 & - & 0.232 & 7.93 & 0.233 \\
\hline $227-30-2,43-45$ & 99.82 & - & 0.442 & 15.04 & 0.443 \\
\hline $227-36-2,73-76$ & 67.50 & - & 0.495 & 24.91 & 0.733 \\
\hline $227-35, \mathrm{CC}$ & 96.80 & - & 0.232 & 8.14 & 0.239 \\
\hline $227-38-1,130-134$ & 100.08 & - & 0.205 & 6.96 & 0.205 \\
\hline $227-41-1,147-150$ & 94.59 & - & 0.212 & 7.61 & 0.224 \\
\hline $227-44-1,90-92$ & 99.86 & - & 0.212 & 7.21 & 0.212 \\
\hline $227-44-2,48-50$ & 81.97 & -- & 0.227 & 9.41 & 0.277 \\
\hline $227-44-2,65-70$ & 100.28 & - & 0.193 & 6.54 & 0.192 \\
\hline $228-35-1,133-135$ & 82.92 & - & 0.256 & 10.49 & 0.308 \\
\hline $228-35-2,14-17$ & 83.91 & - & 0.163 & 6.60 & 0.194 \\
\hline $228-35-2,116-119$ & 96.56 & - & 0.223 & 7.85 & 0.230 \\
\hline $228-35-2,120-125$ & 98.41 & - & 0.155 & 5.35 & 0.157 \\
\hline $228-36-1,133-134$ & 99.69 & -- & 0.451 & 15.37 & 0.452 \\
\hline $228-37-1,145-147$ & 91.96 & - & 0.150 & 5.55 & 0.163 \\
\hline $228-39-1,120-122$ & 90.76 & - & 0.313 & 11.71 & 0.344 \\
\hline $225-24-1,60-63$ & 1.92 & 49.28 & 0.134 & 6.60 & $(\sim 2.2)$ \\
\hline $225-26-1,13-16$ & 11.10 & 31.49 & 0.113 & 7.12 & $\sim 0.82$ \\
\hline $227-31, \mathrm{CC}$ & 1.17 & 3.55 & 0.015 & 8.47 & $\sim 1.02$ \\
\hline $227-36-3,5-7$ & 74.12 & 1.32 & 0.156 & 6.98 & $\sim 0.19$ \\
\hline $\begin{array}{l}225-28-3,95-105 \\
\text { water insoluble } \\
<0.05 \mathrm{~mm} \phi\end{array}$ & 94.57 & - & 0.142 & 5.10 & 0.150 \\
\hline $\begin{array}{l}225-28-3,95-105 \\
\text { water insoluble } \\
<0.2 \mathrm{~mm} \phi\end{array}$ & 98.97 & - & 0.277 & 9.51 & 0.279 \\
\hline
\end{tabular}

Note: All values given in weight- $\%$

According to D'Ans and Kühn (1940) and Kühn (1955), the following marginal values for the different evaporites have been established:

$$
\begin{array}{ll}
\text { boundary anhydrite/halite } & 0.003-0.017 \% \mathrm{Br} / \mathrm{NaCl} \\
\text { boundary halite/polyhalite } & 0.017-0.023 \% \mathrm{Br} / \mathrm{NaCl}
\end{array}
$$

The bromine values found in the Red Sea halites vary from the anhydrite up to the beginning polyhalite region (227-33-1). In some samples, a remarkable polyhalite content is noticed, though the $\mathrm{Br}$ value still corresponds to the anhydrite region (225-29-3; 227-45-1). It is assumed that polyhalite formed synsedimentarily from anhydrite in a relatively shallow basin corresponding to the polyhalite formation described by Holser (1966b) for the recent shallow lagoon Ojo de Liebre. Under such conditions, polyhalite can even occur at a relatively low $\mathrm{Br}$ concentration in the brine.

The $\mathrm{Br}$ content of Site 225 clearly indicates a regressive evaporation, i.e., the $\mathrm{Br}$ values decrease towards the top of the evaporite sequence due to a gradual dilution of the brine.
The $\mathrm{Br}$ values of Site 227 show an evaporation profile ranging from a first halite up to a beginning polyhalite region. The $\mathrm{Br}$ values occasionally vary up to a first halite precipitation $(227-43-5 ; 227-35-5)$. This might be indicative of brine fluctuations and dilutions caused by influx of seawater into the basin. The low Br content of Sample $227-30-2,97-101 \mathrm{~cm}$ suggests a very strong dilution. This salt seems to be recrystallized completely.

In general, the bromine content found in the clear white halite is higher than that of the medium gray halite intervals. This was also observed in the prairie evaporite formation (Saskatchewan) by Wardlaw and Schwerdtner (1966). Mineralogical studies show that the clear white halite seems to be younger and to replace the medium gray halite. This observation is difficult to reconcile with the bromine data. According to Schmalz (1969), the marked density (or salinity) stratification is responsible for the difference in the bromine content. The gray halite ("hopper salt") is thought to have formed at the surface, whereas, the clear halite is assumed to have precipitated in situ on the basin floor.

The bromine content in the halite is a useful means of assessing the brine depth. Bromine may be accommodated in the halite crystal lattice replacing chlorine in solid solution. Progressive evaporation causes a concentration of bromine in the residual brine. Consequently, the halite precipitated from such a residual brine is characterized by a high $\mathrm{Br}$ content. Therefore, the $\mathrm{Br}$ content of the residual brine in a shallow basin should exceed that in a deep-water basin. This principle was applied by Kühn $(1953)^{1}$ to develop an equation to calculate the brine depth from which the halite had precipitated. The samples were taken from a distinct evaporation stage within an "annual layer." The values are given in the following table.

\begin{tabular}{lcccc}
\hline & \multicolumn{2}{c}{ Br Content } & & \\
\cline { 2 - 4 } & $\begin{array}{c}\text { Lower } \\
\text { Sample } \\
\text { Sample }\end{array}$ & $\begin{array}{c}\text { Upper } \\
\text { Sample } \\
\left(\mathrm{b}_{2}\right)\end{array}$ & $\begin{array}{c}\text { Interval } \\
\text { in meters } \\
(\mathrm{m})\end{array}$ & $\begin{array}{c}\text { Calculated } \\
\text { Depth in } \\
\text { meters (T) }\end{array}$ \\
\hline $225-29-3$ & 0.0128 & 0.0137 & 0.025 & $4.7(3.04)$ \\
$227-35-1$ & 0.093 & 0.097 & 0.020 & $5.9(4.0)$ \\
$227-43-2$ & 0.069 & 0.072 & 0.025 & $7.4(5.0)$ \\
\hline
\end{tabular}

In this case, factor $\mathrm{f}=12.3$ for the polyhalite region has been applied. Using factor $f=8$ for the anhydrite region, the depth values decrease even more.

The above table shows that the brine basin was relatively shallow. It is emphasized that the applicability of this method is limited due to the influx and reflux into or out of the basin. Nevertheless, these values may serve as a rough estimate.

$$
\begin{aligned}
1 & \frac{\mathrm{b}_{2} \cdot \mathrm{m}}{\mathrm{b}_{2}-\mathrm{b}_{1}} \cdot \mathrm{f} \quad \mathrm{f}=\frac{2.17 \cdot 100}{\mathrm{~s} \cdot \mathrm{c}} \\
2.17= & \text { specific gravity of } \mathrm{NaCl} \\
\mathrm{s} \quad= & \text { specific gravity of the brine } \\
\mathrm{c} \quad= & \text { medium } \mathrm{NaCl} \text { concentration in oceanic salt systems in } \\
& \text { weight }-\%
\end{aligned}
$$




\section{Rubidium (Rb)}

Rubidium, which can replace potassium diadochically in potassium minerals, is also useful in studying natural salt solutions.

The $\mathrm{Rb}$ content $(0.0014$ weight- $\%)$ found in Samples $225-29-3,40-45 \mathrm{~cm}$ and $227-45-1,75-80 \mathrm{~cm}$ is the highest $\mathrm{Rb}$ value described for polyhalites up to now (cf.Kühn, 1972). Only a polyhalite from Hallstatt, Austria has a comparable $\mathrm{Rb}$ content. The high $\mathrm{Rb}$ values in the Red Sea polyhalites cannot be explained by the normal evaporation of seawater. It is assumed that the brine was relatively enriched in $\mathrm{Rb}$ due to local conditions such as active volcanism accompanied by $\mathrm{Rb}$ rich thermal springs or exhalations. Volcanism is indicated by the abundant volcanic material which is intercalated within the evaporite and thus explains the high $\mathrm{Rb}$ values. For the Hallstadt salts, melaphyre and fine tuffitic layers give evidence of volcanism (Schauberger, 1960) and may be responsible for the high $\mathrm{Rb}$ content.

\section{Strontium (Sr)}

The close geochemical relationship between $\mathrm{Sr}$ and $\mathrm{Ca}$ favors the ionic substitution of $\mathrm{Ca}$ by $\mathrm{Sr}$ in calcium sulphate minerals. The $\mathrm{Sr}$ data furnish valuable information on the genetic character of the salts. The Sr values (referred to pure anhydrite) and the factor $\mathrm{Sr} / \mathrm{Ca} \cdot 1000$ were used to discuss the Red Sea anhydrite deposits. Abundant data from European evaporite deposits concerning the $\mathrm{Sr} / \mathrm{Ca} \cdot 1000$ factor are given by German Muller (1962) and Gerhard Müller (1964). According to Gerhard Müller, Sr/Ca • 1000 data from 1 to 3 are indicative of isomorphous $\mathrm{Sr}$ incorporation; $\mathrm{Sr}$ minerals (mainly strontianite) may form already. Strontium minerals are found at values $>7$, while only celestine should occur in the anhydrite at $\mathrm{Sr}$ values $>20$. Sr values varying less than 20 percent suggest uniform evaporation; whereas, scatter greater than 30 per cent is indicative of irregular changes of the brine, perhaps due to freshwater influx. The $\mathrm{Sr} / \mathrm{Ca} \cdot 1000$ data from the Red Sea samples range between 3.5 and 24.9. Excluding the high value of $24.91(227-36-2,73-76 \mathrm{~cm})$, an average value of $7.8 \pm 2.7$ (scattering of 35 percent) is found. This value corresponds to the oceanic anhydrite region in which a beginning precipitation of $\mathrm{Sr}$ minerals is expected. The high scattering may be explained by irregular sedimentation caused by effluents or brine fluctuations.

According to Usdowski (1973), the Sr content of gypsum at the beginning of the $\mathrm{CaSO}_{4}$ precipitation varies between 0.11 and 0.12 weight- $\%$. At the beginning and at the end of the $\mathrm{NaCl}$ phase, the $\mathrm{Sr}$ content is 0.21 to 0.23 and 0.89 to 0.975 , respectively. The data at the end of the $\mathrm{NaCl}$ precipitation are somewhat uncertain because the isomorphous replacement of $\mathrm{Ca}$ with $\mathrm{Sr}$ takes place simultaneously with the formation of celestine.

If gypsum changes early diagenetically into anhydrite due to a relatively high temperature in the $\mathrm{CaSO}_{4}$ phase of the evaporation, this anhydrite contains $0.229-0.202$ weight-\% Sr according to Usdowski; whereas, primary anhydrite should already have a $\mathrm{Sr}$ value of 0.229 weight-\%.

In general, the Red Sea anhydrite samples are of massive character which suggests their deposition in the $\mathrm{CaSO}_{4}$ phase. On the basis of Usdowski's data, it might be concluded that part of the anhydrite (anhydrite samples having a $\mathrm{Sr}$ content of $<0.229$ ) originated diagenetically from gypsum. The part of the anhydrite having a higher $\mathrm{Sr}$ content $(>0.229$ weight- $\%)$ must be considered to be of primary origin.

The $\mathrm{Sr}$ values of the anhydrites which occur together with carbonate material were calculated according to Usdowski with the distribution factor $b=1200$ for anhydrite and $b=100$ for $\mathrm{CaCO}_{3}$. The high value of Site 225-24-1 is probably indicative of the presence of $\mathrm{Sr}$ minerals. The two samples of the halite phase (225-28-3, $95-105 \mathrm{~cm} ; 0.05 \mathrm{~mm} \phi$ and $0.2 \mathrm{~mm} \phi$ ) show a relatively low SR content; therefore, the thin anhydrite layers within the halite might be conceived as short recurrences back into the $\mathrm{CaSO}_{4}$ phase of evaporation. The $\mathrm{Sr}$ values varying with the grain size might correspond to different generations of $\mathrm{CaSO}_{4}$ growth.

\section{Origin of the Evaporites}

It is assumed that separate great uplifts on either side of the Red Sea during late Eocene and early Oligocene time produced the Ethiopian and Arabian swells with the proto-Red Sea depression separating them (Coleman, this volume). The Miocene transgression of the Mediterranean Sea into this closed depression led to thick evaporite deposits.

Two main problems occur concerning the depositional environment of evaporites. The first problem is whether the evaporites were precipitated under shallow- or deep-water conditions; the second is the question of the depth of the basin in which the evaporites were formed.

The investigation of recent sabkha environments (Tunisia, Libya, Baja California, etc.), especially at Abu Dhabi on the Arabian side of the Persian Gulf (Trucial Coast) (Shearman, 1963; Kinsman, 1966, 1969; Evans, 1966; Kendall and Skipwith, 1969; Butler et al., 1965; Butler, 1969; and others), have provided new models for the interpretation of ancient evaporite deposits. The recent sabkha or tidal flat sediments are characterized by distinct structures such as stromatolites, nodular gypsum and anhydrite, planar and ripple cross-lamination, flat pebble conglomerates, polygonal shrinkage cracks, to mention the most important features. Using recent sabkhas as a guide, much evidence for the presence of former sabkha environments is found in the salt deposits of the geological past (Fuller and Porter, 1969; West, Brandon, and Smith, 1968; Hardie and Eugster, 1971; Shearman and Fuller, 1969; Friedman, 1973).

The petrographic study of the Red Sea evaporites revealed abundant evidence for a sabkha deposit. Undulating laminations composed of semi-opaque or opaque, probably organic-rich, material impregnated with very fine grained dolomite are found within the anhydrites at Site 225 (Cores 24, 25; Figure 15) and Site 227. Finely laminated spheroidal forms consisting of dolomite, organic material, and traces of pyrite are abundant at Site 225, Core 26 (Figure 13). These features are interpreted as algal stromatolites and oncolites which accumulated in shallow water. 
The nodular anhydrites found in the Red Sea evaporite sequence (especially at Site 225, Core 29; Figure 5) are similar to the supratidal anhydrite nodules of recent sabkha deposits. The nodules grow in carbonate sediments above the ground water table and displace the overlying sediments. At a more advanced stage the nodules coalesce. The original boundaries become distorted which results in a mosaic or distorted mosaic structure. Due to continuous growth, the nodules finally merge into one another (enterolithic structure, Shearman, 1963). These different structures can be seen in the Red Sea anhydrites.

The frequent alternations of halite, anhydrite, and dolomitic black shales reflect strong dilutions and reconcentrations of the brine, which seems most likely to be related to a shallow-water environment.

Further support for a salina model for the Red Sea evaporites is given by geochemical studies. Depth calculation by means of the bromine content revealed a very shallow brine depth in the range of some meters. The data obtained by isotope studies (Friedman and Hardcastle, this volume) show a strong influence of fresh water which can only be explained by a salina model. The great variations in the pore water data (Manheim, this volume) also agree with a shallow-water deposit.

Both the petrographical and the geochemical data suggest that the Red Sea evaporites recovered during Leg 23 originated from very shallow water with occasional subaerial exposure.

This assumption, however, does not permit drawing any conclusions on the depth of the basin. The main difficulty with the explanation of ancient salt deposits is the discrepancy between the rate of salt deposition in comparison to the possible rate of basin floor subsidence. These problems have been discussed very carefully by Schmalz (1969). Schmalz showed that this discrepancy can be solved with a deep water-deep basin model. The salts were deposited in basins several hundreds to thousands of meters deep. (The discovery of salts under the Gulf of Mexico (DSDP Leg 1, Ewing et al., 1969) is in excellent agreement with this model). Indeed, the paleogeographic reconstruction of the Red Sea suggests that the proto-Red Sea depression represented a topographic depression of considerable depth. The stratigraphic and structural record indicates that the NW-SE trending depression developed as a trough between the Arabian and African swells rather than as a down-faulted block (Brown and Coleman, 1972; Coleman, this volume). During Miocene time, a great thickness of clastics $(2-3 \mathrm{~km})$ and evaporites $(3-4 \mathrm{~km})$ was deposited in this proto-Red Sea depression as demonstrated by deep exploratory wells (Ahmed, 1972). It is concluded that a "shallow water-shallow basin" model for the evaporite deposits does not agree with this geological information which evidently favors a deposition in a deep basin.

The question which remains to be answered is whether the salts were precipitated in deep water or in very shallow water on the floor of a desiccated deep basin. This problem has been discussed in great detail by Hsü et al. (1973) for the Mediterranean evaporites (DSDP Leg 13). They consider a desiccated deep basin as the only logical alternative to explain the Mediterranean evaporites. The arguments used by these authors against the Schmalz model are not entirely satisfactory. As in the Red Sea, the evaporites recovered in the Mediterranean penetrate only the terminal part of the evaporite sequence. At this final stage, one can also expect a salina or sabkha depositon according to the deep water-deep basin model (see terminal stage II, Figure 8 [nearly filled basin] Schmalz, 1969).

The sedimentological and geochemical studies of the evaporites recovered on Leg 23 reveal convincing evidence of a shallow-water evaporite deposit. However, this evidence should be used with caution. It cannot, necessarily, be taken as an explicit indicator for the total amount of Red Sea evaporites (3-4 km) to be of salina or sabkha origin. Further evidence of the deep strata is necessary and could be provided by the data obtained from deep exploratory wells. Unfortunately, most of these data have not been released for publication by the oil companies.

Leg 23 has proven that Reflector S in the Red Sea is the top of a Miocene evaporite deposit comparable to Reflector $\mathrm{M}$ in the Mediterranean. Assuming a connection between the two basins, the "waterfall" descending from the Strait of Gibraltar must be held responsible not only for the up to two kilometer thick evaporite sequence in the Mediterranean but also for the three to four kilometer thick evaporites in the Red Sea. Hsü et al. (1973) concluded that eight or ten marine invasions could have been sufficient to account for all the salts found under the Mediterranean abyssal plain. Considering the idea of a repeated refilling of the basin during Miocene time, it seems that a desiccated deep-basin hypothesis is not in contrast to the deep water-deep basin model postulated by Schmalz (1969). The desiccated deep-basin model may be regarded as a specific stage in a cycle of repeated refilling and evaporation. Therefore, it is concluded that the origin of the Mediterranean and Red Sea evaporites could be accounted for by Schmalz's "Deep-Water Model" modified by periods of desiccation caused by occasional isolation of the Mediterranean from the Atlantic.

\section{ACKNOWLEDGMENTS}

The senior author is indebted to the entire Leg 23 scientific and technical party for their cooperation aboard the Glomar Challenger. Special thanks are due D. A. Ross, P. R. Supko, and O.E. Weser. The assistance given by F.T. Manheim leading to improvement of the manuscript is greatly appreciated. Part of the work was carried out at Woods Hole Oceanographic Institution; financial support came from NATO. We thank K. H. Ritter for doing the chemical analyses and W. Kücking for preparing the thin sections.

\section{REFERENCES}

Ahmed, S. S., 1972. Geology and petroleum prospects in eastern Red Sea: Am. Assoc. Petrol. Geol. Bull., v. 56, no. 4 , p. $707-719$.

D'Ans, J. and Höfer, P., 1934. Untersuchungen an Brom: Zeitschr. Angew. Chemie, v. 47, p. 71-74.

D'Ans, J. and Kühn, R., 1940. Über den Bromgehalt von Salzgesteinen der Kalisalzlagerstätten: Kali, v. 34, p. 42-46, 59-64, 77-83.

Berger, W. H. and von Rad, U., 1972. Cretaceous and Cenozoic sediments from the Atlantic Ocean. In Hayes, D. E., Pimm, A. C., et al., Initial Reports of the Deep 
Sea Drilling Project, Volume XIV: Washington (U.S. Government Printing Office).

Borchert, H. and Baier, E., 1953. Zur Metamorphose ozeanischer Gipsablagerungen: Neues Jahr. Min., Abhandl., v.86, p. 103-154.

Boeke, H.E., 1908. Über das Kristallisationsschema der Chloride, Bromide, Iodide von Natrium, Kalium und Magnesium, sowie über das Vorkommen des Broms und das Fehlen von Iod in den Kalisalzlagerstätten: Zeitschr. Krist., v. 45A, p. 346-391.

Braitsch, O. and Herrmann, A. G., 1962. Zur Bromverteilung in salinaren Salzsystemen bei $25^{\circ} \mathrm{C}$ : Naturwiss., v. 49 , p. 346.

1963. Zur Geochemie des Broms in salinaren Sedimenten. Teil I. Experimentelle Bestimmung der $\mathrm{Br}-$ Verteilung in verschiedenen natürlichen Salzsystemen: Geochim. Cosmochim. Acta, v. 27, p. 361-391.

Brown, G. F. and Coleman, R. G., 1972. The tectonic frame work of the Arabian Peninsula: Int. Geol. Cong. 24th, Montreal, Sec. 3.

Butler, G. P., 1969. Modern evaporite deposition and geochemistry of coexisting brines, the sabkha, Trucial Coast, Arabian Gulf: J. Sediment. Petrol., v. 39(1), p. 70-89.

Butler, G. P., Kendall, C. G. S. C., Kinsman, D. J. J., Shearman, D. J., and Skipwith, P. A., 1965. Recent evaporite deposits along the Trucial Coast of the Arabian Gulf: Geol. Soc., London Proc., 1623, p. 246-252.

Dellwig, L. F., 1953. Hopper crystals of halite in the salina of Michigan: Am. Mineral., v. 38, p. 730-731. 1968. Significant features of deposition in the Hutchinson Salt, Kansas, and their interpretation: Geol. Soc. Am. Spec. Paper, 88, p. 421.

Ewing, M., Worzel, J. L., Beall, A. O., Berggren, W. A., Bukry, D., Burk, C. A., Fischer, A. G., and Pessagno, E. A., Jr., 1969. Initial Reports of the Deep Sea Drilling Project, Volume I: Washingtom (U. S. Government Printing Office), $672 \mathrm{p}$.

Evans, G., 1966. The recent sedimentary facies of the Persian Gulf region: Royal Soc. London Phil. Trans., ser. A., v. 259, p. 291-298.

Folk, R. L. and Pittman, J. S., 1971. Length-slow chalcedony. A new testament for vanished evaporites: J. Sediment. Petrol., v. 41, no. 4.

Friedman, G. M., 1972. Significance of Red Sea in problem of evaporites and basinal limestones: Am. Assoc. Petrol. Geol. Bull., v. 56, no. 6.

1973. Petrographic data and comments on the depositional environment of the Miocene sulfates and dolomites at Sites 124,132, and 134, western Mediterranean Sea. In Ryan, W. B. F., Hsü, K. J., et al., Initial Reports of the Deep Sea Drilling Project, Volume XIII: Washingtom (U. S. Government Printing Office).

Fuller, J. G. C. M. and Porter, J. W., 1969. Evaporite formation with petroleum reservoirs in Devonian and Mississippian of Alberta, Saskatchewan, and North Dakota: Am. Assoc, Petrol. Geol. Bull., v. 53, p. 909.

Grimm, W. D., 1962. Idiomorphe Quarze als Leitmineralien für salinare Fazies: Erdöl und Kohle, v. 15, p. 880-887.

Hardie, L. A. and Eugster H. P., 1971. The depositional environment of marine evaporites: a case for shallow, clastic accumulation: Sedimentology, v. 16, p. 187.

Herrmann, A. G., 1972. Bromine distribution coefficients for halite precipitated from modern sea water under natural conditions: Contrib. Mineral. Petrol., v. 37, no. 3.
Heybroek, F., 1965; The Red Sea evaporite basin. In Salt basins around Africa: Inst. Petrol. London, p. 17-40.

Holser, W. T., 1966a. Bromide Geochemistry of Salt Rocks. Second Symposium on Salt: Cleveland, Ohio (N. Ohio Geol. Soc. ), p. 248-275.

1966b. Diagenetic polyhalite in recent salt from Baja California: Am. Mineral., v. 51, p. 99-109.

Hsü, K. J., Cita, M. B., and Ryan, W. B. F., 1973. The origin of the Mediterranean evaporites. In Ryan, W. B. F., Hsü, K. J., et al., Initial Reports of the Deep Sea Drilling Project, Volume XIII: Washington (U. S. Government Printing Office).

Kendall, C. G. St. C. and Skipwith, Sir P. A. D’E., 1969. Holocene shallow-water carbonate and evaporite sediments of Khor al Bazam, Abu Dhabi, southwest Persian Gulf: Am. Assoc. Petrol. Geol. Bull., v. 53, p. 841.

Kinsman, D. J. J., 1966. Gypsum and anhydrite of Recent age, Trucial Coast, Persian Gulf. In Raup, J. E. (Ed.) Second Symposium on Salt: Cleveland, Ohio (N. Ohio Geol. Soc.), v. 1, p. 302.

1969. Modes of Formation, sedimentary Associations, and diagnostic Features of Shallow-Water and Supratidal Evaporites: Am. Assoc. Petrol. Geol. Bull., v. 53 , no. 4 .

Kosmahl, W., 1969. Zur Stratigraphie, Petrographic, Paläogeographie, Genese und Sedimentation des Gebänderten Anhydrits (Zechstein 2), Grauen Salztones und Hauptanhydrits (Zechstein 3) in Nordwestdeutschland: Beihefte Geol. Jahr., no. 71.

Kühn, R., 1953. Tiefenberechnung des Zechsteinmeeres nach dem Bromgehalt der Salze: Zeitschr. Deut. Geol. Gesell., v. 105, p. 646-663.

1955. Uber den Bromgehalt von Salzgesteinen, insbesondere die quantitative Ableitung des Bromgehaltes nichtprimärer Hartsalze oder Sylvinite aus Carnallit: Kali und Steinsalz 1, 9, p. 3-16.

1968. Geochemistry of the German Potash Deposits: Geol. Soc. Am. Spec. Paper 88, p. 427-504. 1972. Zur Kenntnis der Rubidiumgehalte von Kalisalzen ozeanischer Salzlagerstätten nebst einigen lagerstättenkundlichen Ausdeutungen: Geol. Jahr., v. 90, p. $127-220$.

Langbein, R., 1961. Zur Petrographie des Hauptanhydrits (Z 3) im Südharz: Chemie der Erde, 21, 2, p. 248-264.

Link, G., 1938. Bildung des Dolomits und Dolomitisierung: Chemie der Erde, v. 16, p. 22-26.

1942. Beobachtungen und ihre Ergebnisse an Gesteinen des mittleren Zechsteins (Hauptdolomit und grauer Salzton) in Thüringen: Chemie der Erde, v. 14, p. 312-357.

Lowell, J. D. and Genik, G. J., 1972. Sea-floor spreading and structural evolution of southern Red Sea: Am. Assoc. Petrol. Geol. Bull., v. 56, p. 247-259.

Maiklem, W. R., Bebout, D. G., Glaister, R. P., 1969. Classification of anhydrite-a practical approach: Bull. Canadian Petrol. Geol., v. 17, no. 2, p. 194-233.

Müller, Gerhard, 1964. Ein Beitrag zur Geochemie des Strontiums in Ca-Sulfat-Gesteinen: Inaugural-Diss. Naturwiss. Fakultät Universität Saarbrücken.

Müller, German, 1962. Zur Geochemie des Strontiums in ozeanischen Evaporiten unter besonderer Berücksichtigung der sedimentären Coelestinlagerstätte von Hemmelte-West (Süd-Oldenburg): Zeitschr. Geol., Jahr. 11, Beiheft 35, p. 1-90 (Akademie-Verlag, Berlin).

Nesteroff, W. D., 1973. Mineralogy, Petrography, Distribution, and Origin of the Messinian Mediterranean evaporites. In Ryan, W. B. F., Hsü, K. J., et al., Initial Reports 
of the Deep Sea Drilling Project, Volume XIII: Washington (U.S. Government Printing Office).

Ogniben, L., 1955. Inverse graded bedding in primary gypsum of chemical deposition: J. Sediment. Petrol., v. 25 , p. 273.

Phillips, J. D. and Ross, D. A., 1970. Continuous seismic reflexion profiles in the Red Sea: Roy. Soc. London Phil. Trans. A., v. 267, p. 143-152.

Ross, D. A., Hays, E. E. and Allstrom, F. C., 1969. Bathymetry and continuous seismic profiles of the hot brine region of the Red Sea. In Hot Brines and Recent Heavy Metal Deposits in the Red Sea: New York (Springer-Verlag).

Schauberger, O., 1960. Melaphyr (Diabas), Tuffit und Krokodolith im Ischler Salzberg, Österreich: Akad. Wiss. Wien. Mathem. Naturwiss. K1., no. 7, p. 133-136.

Schmalz, R. F., 1969. Deep-water evaporite deposition: a genetic model: Am. Assoc. Petrol. Geol. Bull., v. 53, p. 758.

Shearman, D. J., 1963. Recent anhydrite, gypsum, dolomite, halite from the coastal flats of the Arabian shore of the Persian Gulf: Geol. Soc. London. Proc., 1607 , p. 63 .
Shearman, D. J. and Fuller, J. G., 1969. Anhydrite diagenesis, calcitration, and organic laminites, Winnipegosis Formation, Middle Devonian, Saskatchewan: Canad. Petrol. Geol. Bull., v. 17(4), p. 496.

Usdowski, E., 1973. Das geochemische Verhalten des Strontiums bei der Genese und Diagenese von Ca-Karbonat- und Ca-Sulfat-Mineralien: Contri. Mineral. Petrol., v. 38, p. 177-195.

Valyashcko, M. G., 1956. Geochemistry of bromine in processes of salt deposition and the use of the bromine content as a genetic and prospecting criterion: Geochemistry, v. 1, p. 570-589.

Van't Hoff, J. H., 1912. Untersuchungen über die Bildungsverhältnisse der ozeanen Salzablagerungen: Akad. Verlag., Leipzig, 374 pp.

Wardlaw, N. C. and Schwerdtner, W. M., 1966. Haliteanhydrite seasonal layers in the middle Devonian Prairie Evaporite Formation, Saskatchewan, Canada: Geol. Soc. Am. Bull., v. 77, p. 331-342.

West, J. M., Brandon, A. and Smith, M., 1968. A tidal flat evaporitic facies in the Visean of Ireland: J. Sediment. Petrol., v. 38, p. 1079. 